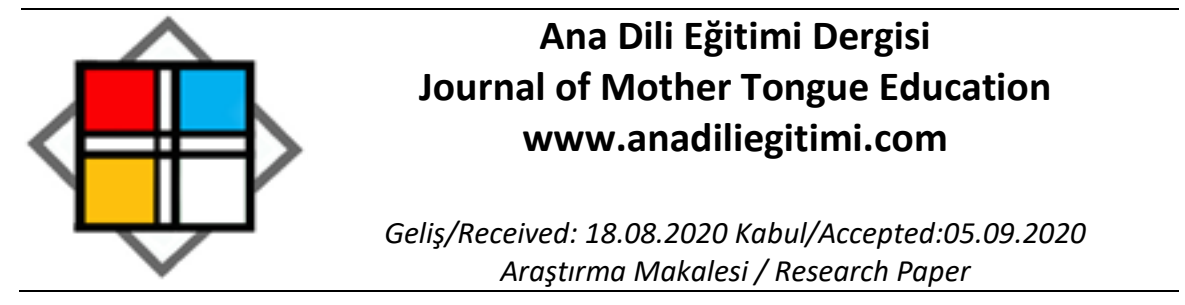

\title{
Türk Dili ve Edebiyatı Öğretmenlerine Göre Okuma Alışkanlığı*
}

\author{
Halit KARATAY** \\ Atilla DiLEKÇi***
}

Öz

Bu araştırmanın amacı, Türk dili ve edebiyatı (TDE) öğretmenlerinin okuma alışkanlığı hakkındaki görüşlerini ortaya koymaktır. Araştırma, durum çalışması olarak tasarlanmışıır. Araştırmaya veri toplamak için 14 TDE öğretmeni ile çalışılmıştır. Öğretmenlerle yapılan görüşmelerin içerik analizi yapılmış, liselerdeki öğrencilerde okuma alışkanlığııın durumu incelenmiştir. Öğretmenler okuma alışkanlığını, sürekli ve düzenli okuma kültürü edinme olarak tanımlamıştır. Bu alışkanlığa sahip öğrencilerin dil becerilerinin diğerlerine göre daha iyi, akademik başarılarının da yüksek olduğunu belirtmişlerdir. Öğretmenlere göre okuma alışkanlığının kazanılmasını engelleyen etmenler şunlardır: internet ve teknoloji araçlarının kullanımı, sosyal medyada geçirilen zaman ve televizyon izleme. Bunlara ayrılan zaman arttıkça öğrencinin kitap okumaya ayırdığı zaman azalmaktadır. Ayrıca okul derslerinin yoğun olması ve öğrencinin özellikle son sınıfta sınavlara hazırlanması okul dışı saatlerde okul derslerinin öncelemesine ve hobi olarak dahi okuma faaliyetinin ihmal edilmesine sebep olmaktadır. Öğrenciler en çok okul ya da halk kütüphaneleri aracılı̆̆ıyla kitaplara erişmektedir. İstedikleri kitap kütüphanelerde yoksa kitapçılardan satın almaktadır. Öğrenciler kitap seçerken sırasıyla en çok; roman, şiir, anı, hikâye, biyografi, efsane türlerini; konu olarak da; macera, fantastik, polisiye, aşk, tarih, korku, bilim kurgu, gençlik, spor ve magazin konularını içeren kitapları tercih etmektedir. Öğrencilerin okuma alışkanlığını geliştirmek için sınıfta; okuma saatleri, kitap söyleşileri, yazar ve eser tanıtımları, okuma grupları, kitapların filmlerinin izlenmesi, okuma dersleri ve yazar söyleşileri yapılabilir. Okulda; kitap okuma yarışmaları, kitap okuma projeleri, kitap kahramanları günü etkinliği, kitap kahramanları tiyatrosu, okul kütüphanesinde okuma etkinlikleri yapılabilir. Öğretmenler okul dışında; kitap fuarı gezileri, kitapla ilgili film izleme gibi etkinliklerin yapılabileceğini belirtmişlerdir. Ayrıca öğretmenler bu konuda öğrencilere iyi bir örnek ve rehber olmalıdır.

Anahtar Kelimeler: Okuma alışkanlığı, okuma motivasyonu, okuma davranışları, lise öğrencileri, edebiyat öğretmeni.

\begin{abstract}
Reading Habits According to Turkish Language and Literature Teachers
Abstract

The purpose of this study is to identify the views of high school Turkish language and literature (TLL) teachers about the reading habit. The research was designed as a case study. Data were collected from $14 \mathrm{TLL}$ teachers through interviews. Content analysis of the interviews was done to examine the reading habits of high school students. In the interviews, the teachers defined the reading habit as acquiring the behavior of doing sustained and regular reading. They also noted that students who had acquired the reading habit were superior in terms of academic achievement than their peers and their language skills were also better. According to the teachers, the factors
\end{abstract}

\footnotetext{
* Araştırmanın etik kurulu izni: Sosyal Bilimlerde İnsan Araştırmaları Etik Kurulu(Protokol No. 2020/155), 25.06.2020, 2020/06

** Prof. Dr., BAiBÜ Eğitim Fakültesi Türkçe Eğitimi Bilim Dalı, Bolu, halitkaratay@gmail.com, ORCID: 0000-00031820-0361.

*** Bolu il Milli Eğitim Müdürlüğü, Bolu, dilekciatilla@gmail.com, ORCID: 0000-0001-5393-9570.
} 
that prevented the acquisition of the reading habit were the use of the internet and technological devices, time spent on social media and watching television. As the time allocated to those increases, the time students allocate to reading books decreases. In addition, the intensiveness of school courses and the final year students' preparation for the upcoming central exams lead to giving priority to studying school subjects during off-school hours and neglect doing reading even as a hobby. The analysis revealed that students accessed books mostly through school or public libraries. If the book they wanted wasn't available in those libraries, they bought it from bookstores. When choosing books, students preferred books in the novel, poem, memoir, story, biography genres, and books that had adventure, fantasy, crime, love, history, horror, science fiction, youth, sport and magazine themes. In order to improve the students' reading habits, the teachers stated that they organized in-class reading hours, book clubs, author and literary work introductions, reading groups, watching movies based on books, reading lessons and author interviews. In addition, the teachers recommended that book reading contests, book reading projects, heroes in books day events, theater performances based on book heroes and reading events may also be held in school libraries. The teachers stated that activities such as trips to book fairs and watching movies based on books could be organized as out-of-school activities. They also emphasized the importance of being a good role-model and guide to the students on the issue.

Keywords: Reading habit, reading motivation, reading behavior, high school students, literature teacher.

\section{Giriş}

Okuma, sembollerin sesletilmesi ve anlamlandırılması sürecini içeren devinişsel ve bilişsel becerilerin eşgüdümlü kullanılmasıyla gerçekleşir. Temel eğitimden itibaren edinilen bu beceri, eğitimin diğer kademelerinde geliştirilir ve yaşam boyu öğrenmenin her alanında kullanılır. Bireyin okuma eylemini belli aralıklarla yapması, yaşamında bir ihtiyaç olarak hissetmesi, zamanla bir okuma ilgisi, tercihleri ve beğenisinin oluşması, onun okuma alışkanlığı kazandığını gösterir. Alanyazında okuma alışkanlığının çeşitli tanımları vardır. Okuma alışkanlığı, bireyin okumayı bir zevk kaynağı olarak algılaması sonucu okuma eylemini sürekli, düzenli ve eleştirel olarak sürdürmesidir (Aksaçlıoğlu ve Yılmaz 2007; Yılmaz, 2004). Okuma alışkanlığı, öğrencilerin okuma türlerini, zevklerini ve sıklığını yansıtan bir davranıştır (Sangkaeo, 1999; Shen, 2006). Okuma alışkanlığı, kişinin okuma eylemini, zevk alarak ve ihtiyaç hissederek hayat boyu sürekli ve düzenli bir şekilde devam ettirmesidir (Uslu Üstten ve Pilav,2014).Bu tanımların ortak özelliği okuma eyleminin bireyde yaşam boyu sürekli ve düzenli bir davranışa dönüşmesidir.

Okuma alışkanlığı sayesinde, öğrenci bilişsel açıdan anlama, analiz etme ve eleştirme becerileri kazanır. Bunların yanında okuma alışkanlığının öğrenciye duyuşsal açıdan başkalarının duygularını anlama, ikilemli olay ve durumlar karşısında doğru davranış ve tercihte bulunma; duyuşsal olarak sosyal hayat için gerekli iletişim becerilerini geliştirme gibi katkıları vardır (Karatay, 2014).Bu alışkanlık öğrencilerin yaşam boyu öğrenme becerileri, öğrenmeyi öğrenme, problem çözme, eleştirel ve yaratıcı düşünme; iletişim kurma ve girişimcilik gibi üst düzey bilişsel ve sosyal becerilerinin gelişimlerini sağlar. Alanyazında okuma alışkanlığı kazanmış öğrencilerin okul derslerinde ve öğrenmede diğer öğrencilere göre daha iyi olduklarını belirleyen çalışmalar vardır (Brown, 1980; Karatay ve Dilekçi, 2020).Okuma alışkanlığı, öğrenciye deneyimler kazandırarak kültürlü ve medeni bir toplumun oluşmasında da önemli bir rol oynar (Oriogu, 2015). Bu kadar önemli bir davranışın öğrencilere kazandırılması uygun ortamın sunulmasına ve bunun önündeki engellerin kaldırılmasına bağlıdır.

Alanyazında öğrencilerin okuma alışkanlığını kazanmasını etkileyen iki temel etmenin olduğu belirlenmiştir. Bunlar; olumlu ve olumsuz etmenler olmak üzere iki ana başlıkta incelenebilir. Öğrencilerin okuma alışkanlığı edinmelerini destekleyici etmenler; kitapların özellikleri (Tella ve Akande, 2007), öğretmen çabası, ailenin okuma üzerindeki hassasiyeti, nitelikli kitaplık ya da kütüphaneye erişim ve öğrencinin okuma isteğidir. Öğrencilerin okuma alışkanlığı kazanmasını engelleyen etmenler ise; televizyon izleme (Tella ve Akande, 2007), internet ve sosyal medya kullanımı, ev ödevlerinin çok olması, okul programlarının yoğunluğu, okuma konusunda ilgisiz aile ve sosyal çevrenin varlığı, öğrencinin ilgi ve düzeyine uygun kitaba erişememesi ve öğrencinin istekli olmamasıdır. 
Öğrencilerin okuma alışkanlıkları ve tercihleri üzerine farklı düzeylerde gerçekleştirilen çok sayıda araştırma vardır. Araştırmalar öğrencilerin kitap türü, konusu, tercih edilen kitapların biçimsel özellikleri, cinsiyetlerine göre okuma alışkanlıkları üzerine odaklanmıştır (Clark ve Foster, 2005; Hopper, 2005;Karatay ve Dilekçi, 2020; Majid ve Tan, 2007; Mohr, 2006; Ogunrombi ve Adio, 1995; Oriogu, 2015; Rimensberger, 2014; Sangkaeo, 1999; Summers, 2013; Tella ve Akande, 2007; Wicks, 1995; Zickuhr, Rainie, Purcell, Madden ve Brenner, 2012).

Öğrenciler yaş ve cinsiyetten bağımsız olarak genellikle roman ve hikâye okumayı tercih ederler (Vostrovsky, 1899). Öğrencilerin konu seçimi yaş ve cinsiyetlerine göre değişmekle birlikte temel eğitim öğrencileri konu olarak en çok macera, gizem, suç ve mizah konularını tercih etmektedirler (Majid ve Tan 2007). Cinsiyetin, okuma alışkanlığını etkilediği çeşitli araştırmalarda vurgulanmıştır(Wicks, 1995; Vostrovsky, 1899). Vostrovsky (1899), 9-19 yaş arası yaklaşık 1200 öğrencinin katılımı ile gerçekleştirdiği araştırmada okuma alışkanlığı bakımından erkek ve kız çocukları arasında çeşitli farklılıkların olduğunu belirlemiştir. Kız çocuklarının daha çok iç dünyalarını yansıtan kitaplardan, erkek çocuklarının ise macera kitaplarından hoşlandığını bulmuştur. Wicks (1995), 13-15 yaş arası erkek çocukların okuma alışkanlıkları ve kitap seçimleri üzerine yaptığı araştırmada erkek çocukların kurgu kitaplarını tercih ettiğini ortaya koymuştur.

Okuma alışkanlığın kazandırılmasında aileler, sosyal çevre, okullar ve kütüphaneler etkilidir (Clark, 2010; Gaona ve González, 2011; Oriogu, 2015; Wicks, 1995; Yılmaz, 2004; Zickuhr vd., 2012).Okuma alışkanlığının kazandırılması sürecinde kitaplar üzerine kurulan sosyal etkileşim, yüksek bilişsel kavrama ve okuma isteği oluşmasında önemlidir. Öğrenci okuduğunu, öğrendiğini paylaşmak ister. Bu paylaşım öğrencilerle konuşarak, tartışarak gerçekleşir. Okuduğunu paylaşma fırsatı olmayan yalıtılmış okumalar, okuma isteksizliği oluşturur. Öğretmenlerin ve ailelerin okumanın sığ okuryazarlıktan öte üst düzey sürekli bir beceri olarak edinilmesi için çaba göstermeleri gerekir.

Öğrencilerin kitapları nereden temin ettiklerine yönelik yapılan araştırmalarda ortaokul öğrencilerinin kitaplarını en çok sınıf kitaplığından, kütüphanelerden, öğretmenlerinden, ailelerinden ve arkadaşlarından elde ettikleri tespit edilmiştir (Karatay ve Dilekçi, 2020; Majid ve Tan, 2007; Tella ve Akande, 2007). Temel eğitimden farklı olarak 16-17 yaş arası gençler ise okuma materyali almak için en çok kütüphanelere başvururlar (Zickuhr vd. 2012).

Okuma alışanlığını temel eğitim dönemine göre gençlik döneminde kazanmak daha zordur (Uslu Üstten ve Pilav, 2014). Gençlik çağındaki öğrencilerin dil ve edebiyat derslerine TDE öğretmenleri girer. Bundan dolayı lise çağındaki öğrencilerin var olan okuma alışkanlığını geliştirmek ve bu alışkanlığı edinemeyenlerin edinmesini sağlamak onların rehberliği ve ilgisine bağlıdır. Öğretmenlerin, ders içi uygulamalarla öğrencilerin okuma alışkanlığını pekiştirmeleri ve okul dışında onlara ortamlar sunmaları, öğrencilerin uygun kitaplar seçmelerine rehberlik etmeleri gerekir.

Okuma alışkanlığı ile ilgili çalışmalar incelendiğinde bunların genellikle öğrencilerin okuma alışkanlığı ve tercihleri üzerine olduğu görülür. Bunlardan daha önemlisi öğretmenlerin okuma alışkanlığı kazandırma sürecinde öğrencilerine doğru rehberlik edip etmediklerinin ve bu konudaki donanımlarının yeterliliğinin belirlenmesidir. Bu araştırmada TDE öğretmenlerinin okuma alışkanlığını nassıl tanımladıkları, öğrencilerde okuma alışkanlığına sahip olma ölçütü, okuma alışkanlığına sahip öğrencilerin özellikleri, gençlik çağındaki öğrencilerin okuma ilgileri ve tercihleri, kitaba nasıl eriştiklerinin belirlenmesi ve lise çağındaki öğrencilerin okuma alışkanlığının geliştirilmesi için sınıfta, okulda, okul dışında yaptıklarının ortaya konulması amaçlanmıştır. Böylelikle öğretmenlerin bu konuda yeteri kadar donanımlı olup olmadıkları belirlenmiş ve intiyaç duydukları alanlarda onlara destek sağlanması için önerilerde bulunulmuştur.

Türk dili ve edebiyatı öğretmenlerinin öğrencilerin okuma alışkanlıkları ile ilgili görüşleri nelerdir?

1. TDE öğretmenlerine göre okuma alışkanlığı nedir?

2. TDE öğretmenlerine göre bir öğrencinin okuma alışkanlığına sahip olma ölçütü nedir?

3. TDE öğretmenlerine göre okuma alışkanlığı ile akademik başarı arasında bir ilişki var mı?

4. TDE öğretmenlerine göre okuma alışkanlığını geliştirmek için sınıfta yapılabilecek etkinlikler nelerdir? 
5. TDE öğretmenlerine göre okuma alışkanlığını geliştirmek için okulda yapılabilecek etkinlikler nelerdir?

6. TDE öğretmenlerine göre okuma alışkanlığını geliştirmek için okul dışında yapılabilecek etkinlikler nelerdir?

7. TDE öğretmenlerine göre öğrencilerin okuma alışkanlığı kazanmalarını engelleyen etmenler nelerdir?

8. TDE öğretmenlerine göre okuma alışkanlığı kazanmış ve kazanmamış öğrenciler arasında ne gibi farklılıklar vardır?

9. TDE öğretmenlerine göre öğrencilerin okuma ilgileri ve tercihleri nelerdir? Bunları neler etkiler?

10. TDE öğretmenlerine göre öğrencilerin kitap okuma nedenleri nelerdir?

11. TDE öğretmenlerine göre öğrenciler kitaplara nasıl erişmektedir?

\section{Araştırmanın Yöntemi ve Deseni}

\section{Yöntem}

Bu araştırma TDE öğretmenlerinin lise öğrencilerinin okuma alışkanlıklarıyla ilgili görüşleri üzerinedir. Araştırma, nitel araştırma yöntemlerinden durum çalışmasına göre desenlenmiştir.

Durum çalışması, bireylerin deneyimlerine dayanarak bağlama göre düşüncelerini ve bunların sebeplerini sorgulamayı sağlar (Gillham, 2000). Olayları, olguları anlamak ve açıklamak öğretim programlarına, öğrenme durumlarına ya da araştırmalara yol gösterme özeliği taşır (Merriam, 1990).

Öğrencilerin eğitim ve meslek yaşamlarını başarılı sürdürebilmeleri için okuma alışkanlığı edinmeleri gerekir. Bu alışkanlığı öğrencilere edindirmek ve geliştirmek için öğrencilerin ilgilerini, tercihlerini, öğretmenlerin okuma etkinliklerini, uygulamalarını belirleyerek ilgili yeni bir bakış açısı ve çözüm önerileri sunmak önemlidir. Bu olguyla ilgili veri toplamak için araştırma, sistematik durum çalışması şeklinde tasarlanmıştır. Sistematik durum çalışması modeli; araştırma sorularının ve alt sorularının geliştirilmesi, çalışılacak durumun belirlenmesi, araştırmaya katılacak bireylerin seçimi, verilerin toplanması ve alt problemlerle ilişkilendirilmesi, verilerin analizi, yorumlanması ve durumun raporlaştırılması süreçlerini içerir (Yıldırım ve Şimşek, 2013). Araştırma süreci bu işlem basamaklarına göre planlanmıştır.

\section{Araştırmanın Çalışma Grubu}

Araştırmada çalışma grubu amaçlı örnekleme yöntemlerinden ölçüt örnekleme yöntemiyle belirlenmiştir. Bu örnekleme yönteminde çalışma konusu ile ilgili birincil kişiler seçilerek birinci ağızdan konu ile ilgili veri toplanır. Araştırma, 2019-2020 Eğitim-Öğretim yılında MEB'deki ortaöğretim kurumlarında görev yapan gönüllü 14 Türk dili ve edebiyatı öğretmeni ile yürütülmüştür. Her bir öğretmen farklı okul türünden ve farklı bir okuldan seçilmiştir. TDE öğretmenlerine ait kişisel bilgiler Tablo 1'de sunulmuştur.

Tablo 1.

Çalışma Grubundaki TDE Öğretmenlerine iliş̧kin Bilgiler

\begin{tabular}{llll} 
Kişisel Bilgiler & & $f$ & $\%$ \\
\hline \multirow{2}{*}{ Cinsiyet } & Kadın & 9 & 64 \\
& Erkek & 5 & 36 \\
\hline \multirow{4}{*}{ Hizmet yılı } & $0-5$ yıl & 1 & 7 \\
& $6-10$ yıl & 1 & 7 \\
& $11-15$ yıl & 3 & 21 \\
& $16-20$ yıl & 3 & 21 \\
Okul türü & Anadolu lisesi & 6 & 43
\end{tabular}




$\begin{array}{lll}\text { Meslek lisesi } & 4 & 29 \\ \text { Imam-Hatip Lisesi } & 3 & 21 \\ \text { Fen lisesi } & 1 & 7\end{array}$

Araştırmaya katılan TDE öğretmenlerinin 9'u kadın, 5'i erkektir. Hizmet yılı olarak öğretmenlerin 1'i 0-5 yıl, 1'i 6-10 yıl, 3'ü 11-15 yıl, 3'ü 16-20 ve 6'sı 21-25 yıllık mesleki tecrübeye sahiptir. Öğretmenlerin 6'sı anadolu lisesi, 4'ü meslek lisesi, 3'ü imam-hatip lisesi ve $1^{\prime}$ 'i fen lisesinde görev yapmaktadır.

\section{Veri Toplama Aracı ve Süreci}

Araştırmanın yöntem ve desenine uygun olarak nitel veri toplama tekniklerinden yarı yapılandırılmış görüşme tekniği kullanılmıştır. Yarı yapılandırılmış görüşme tekniğinde katılımcıların olgu ile ilgili düşüncelerini ortaya koymak, veri olarak elde etmek amacıyla araştırmacılar katılımcılara açık uçlu sorular sorar. Bu sorular ile ilgili araştırmalar okunduktan sonra iki alan uzmanı, 13 soruluk "Okuma Alışkanlığı Görüşme Formu (OAGF)" hazırlamıştır. Alan uzmanları ile yapılan değerlendirmeler sonucunda kapsam geçerliliği dikkate alınarak bu görüşme formundaki soru sayısının 11 olmasına karar verilmiştir.

Veri toplama aracı hazırlandıktan sonra farklı türdeki liseler belirlenmiş ve bu okullarda görev yapan bir TDE öğretmenine ulaşılarak çalışmanın konusu ve amacı açıklanmıştır. Konu ile ilgilenen gönüllü öğretmenlerle veri toplama formu verilerek yazılı olarak görüşlerini yazmaları istenmiştir.

\section{Verilerin Analizi}

Araştırma için OAGF ile elde edilen öğretmen görüşlerinin içerik analizi yapılmıştır. Öğretmenlerin her bir soruya verdikleri cevaplar bir araya getirilmiştir. Öğretmenlerin görüşleri, ilgili oldukları ana ve alt temaların altına ... K1, K2... şeklinde kodlanmıştır. Öğretmenlerin görüşleri bu temalar altında sıklıkları yüksekten düşüğe doğru sıralanmış, daha anlaşılır olması için tablo hâline getirilmiş ve yorumlanmıştır. Konu ile ilgili yapılan değerlendirmeleri desteklemek için öğretmen görüşlerinden örnekler de sunulmuştur.

\section{Geçerlik ve Güvenirlik}

Nitel bir araştırmada geçerliğin sağlanması için veriler detaylı olarak kaydedilir ve araştırmacılar tarafından sonuca ulaşma sürecinin açıklanması gerekir (Yıldırım ve Şimşek, 2013).Araştırmanın geçerliğini sağlamak için alanyazında okuma alışkanlığı ile ilgili yapılan çalışmalar incelenmiş ardından iki alan uzmanın görüşleri alınarak OAGF oluşturulmuştur. Ön uygulama yapıldıktan sonra cevabı tekrar eden sorular çıkarılarak OAGF'ye son şekli verilmiştir.

Araştırmacılar, araştırmanın güvenirliğini için görüşme metinlerini birbirinden bağımsız olarak değerlendirmiştir. Ardından birbirine yakın cevaplar iki alan uzmanı tarafından okunmuş, ana ve alt temalar altında kodlanmıştır. Değerlendirme sonrasında araştırmacılar bulgularını karşılaştırıımış \% 90 oranında temalarda görüş birliğinin olduğu belirlenmiştir. Uzmanlar görüş ayrılığı olan maddeleri tekrar birlikte değerlendirerek ilgili oldukları temaların altına kodlanmasına karar vermişlerdir. Böylelikle yapılacak değerlendirmeler için görüş birliğine ulaşılmıştır.

\section{Etik Kurulu i̇zi}

Sosyal Bilimlerde Insan Araştırmaları Etik Kurulunda (Protokol No. 2020/155) araştırma 25.06.2020 tarihli 2020/06 toplantısında etik olarak uygun bulunmuştur. Katılımcılara görüşme öncesinde "bilgilendirilmiş gönüllü olur/onam formu" imzalatılmıştır Böylelikle araştırma sürecinde yayın etiğine uyulmuştur. 


\section{Problem}

\section{Bulgular}

Bu problemin çözümünde TDE öğretmenlerinin okuma alışkanlı̆̆ının ne olduğu hakkındaki görüşlerinin içerik analizinden yararlanılmıştır. Öğretmenlerin okuma alışkanlığı ile ilgili tanımları Tablo 2 'de verilmiştir.

Tablo 2.

TDE Öğretmenlerinin Okuma Alışkanlığı Tanımları

\begin{tabular}{|c|c|c|c|c|c|c|}
\hline & Tema & Okuma alışkanlığı tanımı & Katılımcılar & $\mathrm{n}$ & $\mathrm{N}$ & $\%$ \\
\hline \multirow{3}{*}{1.} & \multirow{3}{*}{$\begin{array}{l}\text { Okuma ilgi ve } \\
\text { isteği }\end{array}$} & 1. Okuma isteği, ilgisi ve sevgisi & $\mathrm{K}_{3,4,5,7,11,12}$ & 6 & 14 & 43 \\
\hline & & 2. Okumayı ihtiyaç görmektir. & $\mathrm{K}_{4,6,10,12}$ & 4 & 14 & 28 \\
\hline & & $\begin{array}{l}\text { 3. Uyarmadan okuma eylemini } \\
\text { yapmaktır. }\end{array}$ & $\mathrm{K}_{10}$ & 1 & 14 & 7 \\
\hline \multirow{5}{*}{2.} & \multirow{5}{*}{$\begin{array}{l}\text { Sürekli ve } \\
\text { düzenli okuma }\end{array}$} & 1. Bilinçli ve düzenli okuma & $\mathrm{K}_{2,8,12,14}$ & 4 & 14 & 28 \\
\hline & & 2. Belli aralıklarla okuma & $\mathrm{K}_{4}$ & 1 & 14 & 7 \\
\hline & & 3. Ayda 4-5 kitap okumak & $\mathrm{K}_{9}$ & 1 & 14 & 7 \\
\hline & & 4. Okumaya zaman ayırmak & $\mathrm{K}_{11}$ & 1 & 14 & 7 \\
\hline & & 5. Okumak bir yaşam tarzıdır. & $\mathrm{K}_{12}$ & 1 & 14 & 7 \\
\hline 3. & $\begin{array}{l}\text { Eleştirel } \\
\text { Düşünme }\end{array}$ & 1. Olaylara geniş bakmak & $\mathrm{K}_{1}$ & 1 & 14 & 7 \\
\hline
\end{tabular}

TDE öğretmenlerinin okuma alışkanlığının ne olduğu hakkındaki tanımları 3 ana tema,9alt tema altında toplanmıştır. 3 ana temanın okuma ilgi ve isteği, sürekli ve düzenli okuma, eleştirel düşünme şeklinde ifade edilebileceği görülmektedir.

\section{Okuma ilgi ve isteği}

Uygulamaya katılan 11 öğretmen, "Okuma isteği duyup kitaplara karşı ilgili olmaktır (K3), Severek ve isteyerek okumaktır (K5),Okuma isteği duymaktır (K4)..." ifadeleriyle okuma alışkanlığııın tanımında bireysel ilgi ve isteğe dikkat çekmişlerdir. Öğretmenler okuma alışkanlığını bireyin içinden gelen okuma isteği olarak tanımlamaktadır.

\section{Sürekli ve düzenli okuma}

Öğretmenlerin, okuma alışkanlığı ile ilgili bir diğer tanımları bu eylemin sürekli ve düzenli olmasıdır. Uygulamaya katılan öğretmenlerden 7'si, "Kişinin okuma eylemini düzenli biçimde gerçekleştirmesidir (K14), Bilinçli olarak düzenli aralıklarla okuma (K2), Aylık yaklaşık 4-5 kitap okumaktır (K9), Belli aralıklarla kitap okumak, okumanın alışkanlığa dönüştüğünün göstergesidir (K4), Düzenli olarak kitap okumaktır (K8)..."ifadeleriyle okumanın sürekliliğini ve düzenli oluşunu tanımlamışlardır.

\section{Eleştirel düşünme}

Uygulamaya katılan 1 öğretmen, "İnsanoğlunun at gözlüklerini çıkarıp olaylara üç boyutlu bakabilmesidir (K1)..." ifadesiyle okuma alışkanlığıyla eleştirel düşünebilmeyi eş tutmuştur. Yani eleştirel düşünme becerisine sahip olabilmek için okuma alışkanlığının temel olduğunu vurgulamıştır. 


\section{Problem}

Bu problemin çözümünde TDE öğretmenlerinin, öğrencilerinin okuma alışkanlığına sahip olma ölçütlerine yönelik görüşlerinin incelenmesinden yararlanılmıştır. Bununla ilgili bulgular Tablo 3 'te verilmiştir.

Tablo 3.

Okuma Alışkanlığına Sahip Olma Ölçütü

\begin{tabular}{|c|c|c|c|c|c|c|}
\hline & Tema & $\begin{array}{l}\text { Bir öğrencinin okuma alışkanlığına sahip } \\
\text { olma ölçütü }\end{array}$ & Katılımcılar & $\mathrm{n}$ & $\mathrm{N}$ & $\%$ \\
\hline \multirow{4}{*}{1.} & \multirow{4}{*}{$\begin{array}{l}\text { Sürekli ve düzenli } \\
\text { okuma }\end{array}$} & 1. Günlük okuma yapma & $\mathrm{K}_{1,8,9,14}$ & 4 & 14 & 28 \\
\hline & & 2. Okuma eyleminin sürekli yapılması & $\mathrm{K}_{2,5,11,13}$ & 4 & 14 & 28 \\
\hline & & 3. Ayda en az 2 kitap okuma & $\mathrm{K}_{4,7}$ & 2 & 14 & 14 \\
\hline & & 4. Başladığı kitabı bitirme & $\mathrm{K}_{4}$ & 1 & 14 & 7 \\
\hline & \multirow{3}{*}{$\begin{array}{l}\text { Okuma ilgi ve } \\
\text { isteği }\end{array}$} & 1. Okuma isteğinin olması & $\mathrm{K}_{5,6,12,13}$ & 4 & 14 & 28 \\
\hline & & 2. Kitap arayışında olma & $\mathrm{K}_{3}$ & 1 & 14 & 7 \\
\hline & & 3. Yanında kitap taşıma & $\mathrm{K}_{10}$ & 1 & 14 & 7 \\
\hline \multicolumn{2}{|c|}{$\begin{array}{l}\text { 3. Uygulama } \\
\text { becerisinin } \\
\text { gelişmesi }\end{array}$} & 1. Okuduklarını yaşama aktarabilmesi & $\mathrm{K}_{1}$ & 1 & 14 & 7 \\
\hline
\end{tabular}

Okuma alışkanlığına sahip olma ölçütleri öğretmenlerin görüşlerine göre; sürekli ve düzenli okuma, okuma ilgi ve isteği, uygulama becerisinin gelişmesi olmak üzere 3 ana tema ve 8 alt tema altında toplandığı belirlenmiştir.

\section{Sürekli ve düzenli okuma}

Öğretmenler, öğrenciler için okuma alışkanlığı ölçütünün özellikle günlük, sürekli ve düzenli yapılması olduğunu belirtmişlerdir. Uygulamaya katılan öğretmenlerden $10^{\prime} \mathrm{u}$, planlı ve sürekli okumanın alışkanlık için ölçüt olduğunu vurgulamışlardır. Öğretmenlere göre öğrencilerin okuma alışanlığına sahip olma ölçütleri şunlardır: "Okumak için her fırsatı değerlendirmesi, okumayı bırakmamasıdır (K5), Ölçütümüz öğrencinin düzenli olarak kitap okumasıdır (K8), Ayda en az 4-5 kitap okunmasıdır (K7), Günde 25 sayfadan az olmamak şartıyla her gün bir saat diliminde bu eylemi gerçekleştiriyor olabilmesidir (K14)...”. Araştırmaya katılan öğretmenlerinin çoğu okuma alışkanlığını, sürekli ve düzenli yapılan bir eylem ve başlanılan kitabın bitirilmesi olarak değerlendirmektedir.

\section{Okuma ilgi ve isteği}

Uygulamaya katılan 7 öğretmen, "Okumak için her fırsatı değerlendirmesi, okumayı bırakmamasıdır (K5), Kitap okuma isteğinin olması (K13), Okuyor olduğu kitabı bitirince daha sonra okuyacağı kitap arayışına girmesidir (K3), Okuduğu kitabın her zaman elinin altında bulunması (K10)..." ifadeleriyle okuma alışkanlığının tanımında ölçüt öğrencinin ilgi ve isteğidir. Öğrencilerin telkin ya da zorlama olmaksızın içsel bir istekle kitap okuması, kitaplara ilgi duyması okuma alışkanlığı kazandığı anlamına gelir.

\section{Uygulama becerisinin gelișmesi}

Araştırmaya katılan 1 öğretmen, "Okumak iyidir ama bir yere kadar ondan sonrası tembelliktir. Okuyan onu imbikten geçirip aktarmazsa bir işe yaramaz ve kitap yüklü bir eşekten farkı kalmaz (K1)..." ifadesiyle öğrencilerin okumalardan edindiği bilgileri günlük yaşamlarında uygulayabilmeyi ölçüt olarak kabul etmiştir. 


\section{Problem}

Bu problemin çözümünde TDE öğretmenlerinin, okuma alışkanlığı ile akademik başarı arasındaki ilişkiye yönelik görüşlerinin incelenmesinden yararlanılmıştır. Bununla ilgili bulgular Tablo 4'te verilmiştir.

Tablo 4.

TDE Öğretmenlerine Göre Okuma Alışkanlığı ile Akademik Başarı Arasındaki ilişski

\begin{tabular}{|c|c|c|c|c|c|}
\hline Tema & $\begin{array}{l}\text { Okuma alışkanlığı ile akademik başarı arasındaki } \\
\text { ilişki }\end{array}$ & Katılımcılar & $\mathrm{n}$ & $\mathrm{N}$ & $\%$ \\
\hline \multirow{4}{*}{$\begin{array}{l}\text { Akademik } \\
\text { başarıyı } \\
\text { geliştirir }\end{array}$} & 1. Okuma anlamayı geliştirir. & $\mathrm{K}_{1,3,4,6,8,9,12,13}$ & 8 & 14 & 58 \\
\hline & 2. Okuma üst düzey düşünmeyi geliştirir. & $\mathrm{K}_{4,6,9,13}$ & 4 & 14 & 28 \\
\hline & 3. Okuma dil becerilerini geliştirir. & $K_{2,5,6}$ & 3 & 14 & 21 \\
\hline & 4. Okuma, akademik başarıyı artırır. & $K_{7,10,14}$ & 3 & 14 & 21 \\
\hline 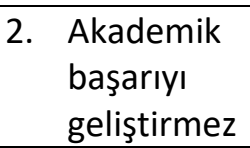 & $\begin{array}{l}\text { 1. Okuma ile akademik başarı arasında ilişki } \\
\text { yoktur. }\end{array}$ & $\mathrm{K}_{11}$ & 1 & 14 & 7 \\
\hline
\end{tabular}

Okuma alışkanlığı ile akademik başarı arasındaki ilişki öğretmenlerin görüşlerine göre; akademik başarıyı geliştirir ve akademik başarıyı geliştirmez olmak üzere 2 ana tema ve 5 alt tema altında toplandığı belirlenmiştir.

\section{Akademik başarıyı geliş̧irir}

Öğretmenler, okuma alışkanlığı ve akademik başarı arasında olumlu bir ilişki olduğunu belirtmişlerdir. Uygulamaya katılan öğretmenlerden 13'ü, okul başarısının temelinde okuma alışkanlığının olduğunu vurgulamışlardır. Öğretmenler, okuma ve akademik başarı arasındaki ilişkiyi şu şekilde ifade etmişlerdir: "Okuma alışkanlığı anlama, algılama düzeyini artırdığından akademik başarıya olumlu etkisi vardır (K3), ikisi de doğru orantılıdır (K1), Sadece okuma alışkanlığı gelişmiş bir öğrenci derslerine hiç çalışmasa bile belli seviyede başarı gösterir. Konuşması, yorum yapması, hızlı düşünüp anlam farklarını ve verilmek isteneni çözebilme hızı olumlu yönde değişir (K4)...". Bu görüşlere göre öğretmenler, öğrencilerinin okuma alışkanlığı ile akademik başarıları arasındaki ilişkinin farkındadır.

\section{Akademik başarıyı geliştirmez}

Uygulamaya katılan 1 öğretmen, “Hayal gücü okumakla kazanılacak bir yetenek değil (K15) "ifadesiyle okuma alışkanlığının, akademik başarıyı etkilemediğini ve hayal gücünü geliştirmediğini düşünmektedir.

\section{Problem}

Bu problemin çözümünde TDE öğretmenlerinin, öğrencilerinin okuma alışkanlığını geliştirmek için sınıfta yapılabilecek etkinliklere yönelik görüşlerinin incelenmesinden yararlanılmıştır. Bununla ilgili bulgular Tablo 5 'te verilmiştir.

Tablo 5.

TDE Öğretmenlerine Göre Okuma Alışkanlığı İçin Sınıfta Yapılabilecek Etkinlikler

\begin{tabular}{clllccc}
\hline \multicolumn{1}{c}{ Tema } & Okuma alışkanlığını sınıfta geliştirici etkinlikler & Katılımcılar & $\mathrm{n}$ & $\mathrm{N}$ & $\%$ \\
\hline & & & $\mathrm{K}_{1,2,4,6,7,8,9,12,}$ & & & \\
& & 1. & Okuma saatleri & 13,14 & 14 & 78 \\
1. Okuma & 2. Kitap söyleşileri & $\mathrm{K}_{1,3,4,10,12}$ & 5 & 14 & 35 \\
etkinlikleri & 3. & Yazar ve eser tanıtımları & $\mathrm{K}_{7,14}$ & 2 & 14 & 17 \\
& 4. & Okuma grupları & $\mathrm{K}_{4}$ & 1 & 14 & 7 \\
& 5. & Kitapların filmlerinin izlenmesi & $\mathrm{K}_{4}$ & 1 & 14 & 7
\end{tabular}




\begin{tabular}{lllll} 
6. Okuma dersleri & $\mathrm{K}_{11}$ & 1 & 14 & 7 \\
7. Yazar söyleşileri & $\mathrm{K}_{12}$ & 1 & 14 & 7 \\
\hline
\end{tabular}

2. Öğrencinin ilgi ve seviyesini

1. Öğrenci ilgi ve seviyesine uygun

tanıma

kitaplar

3. Öğretmenin

1. Okuyan öğrencileri ödüllendirme

2. Öğretmenin model olması

rehberliği

3. Öğretmenin çabası

\begin{tabular}{lccc}
$\mathrm{K}_{2,5}$ & 2 & 14 & 14 \\
\hline $\mathrm{K}_{4,5,9}$ & 3 & 14 & 21 \\
$\mathrm{~K}_{1,4}$ & 2 & 14 & 14 \\
$\mathrm{~K}_{1}$ & 1 & 14 & 7 \\
$\mathrm{~K}_{13}$ & 1 & 14 & 7
\end{tabular}

Okuma alışkanlığını geliştirmek için sınıfta yapılabilecek etkinliklerin öğretmenlerin görüşlerine göre okuma etkinlikleri, öğrencinin ilgi ve seviyesini tanıma, öğretmenin rehberliği olmak üzere 3 ana tema ve 12 alt tema altında toplandığı belirlenmiştir.

\section{Okuma etkinlikleri}

Uygulamaya katılan 13 öğretmen, "Haftanın her günü bir ders saati kitap okuma saatimiz var. Ayrıca kitap tanıtım günlerimiz var (K14), Okuma grupları oluşturmak, aynı kitabı okutup sohbet ettirmek. Kitapların filmlerini izletmek (K4), Yaşayan şair ve yazarlarla görüşme imkânı sağlanabilir (K12)..."ifadeleriyle öğrencinin okuma alışkanlığını kazanması için okuma etkinliklerinin etkili olduğunu belirtmiştir.

\section{Öğretmenin rehberliği}

Uygulamaya katılan 5 öğretmen, bu alışkanlığın edinilmesinde rehberliğin önemli olduğunu belirtmiştir: "Öğretmen okuma konusunda örnek olmalıdır (K4), Her ayın sonunda okunan sayfa sayısına göre en fazla okuyan ödüllendirilmelidir (K9), Yazilılarda kitaplarla ilgili sorular sormak (K13)...". Bu ifadeler, okuma alışkanlığının kazandırılmasında öğretmenin bu konudaki hassasiyeti ve örnek olması, öğrencilere rehberlik etmesinin önemli olduğunu göstermektedir.

\section{Öğrencinin ilgi ve seviyesini tanıma}

Uygulamaya katılan 2 öğretmen, "Öğrencilerin yaşına ve ilgilerine uygun eserler okumalarını sağlamak (K5)..." ifadeleriyle okuma alışkanlığını kazandırmak için öğrencilerin ilgilerini çeken ve seviyelerine uygun kitaplar verilmesinin önemli olduğunu belirtmiştir.

\section{Problem}

Bu problemin çözümünde TDE öğretmenlerin, öğrencilerinin okuma alışkanlığını geliştirmek için okulda yapılabilecek etkinliklere yönelik görüşlerinin incelenmesinden yararlanılmıştır. Bununla ilgili bulgular Tablo 6'da verilmiştir.

Tablo 6.

TDE Öğretmenlerine Göre Okuma Alışkanlığını Geliştirmek İçin Okulda Yapılabilecek Etkinlikler

\begin{tabular}{|c|c|c|c|c|c|c|}
\hline & Tema & $\begin{array}{l}\text { Okuma alışkanlığını okulda geliştirici } \\
\text { etkinlikler }\end{array}$ & Katılımcılar & $\mathrm{n}$ & $\mathrm{N}$ & $\%$ \\
\hline \multirow{6}{*}{\multicolumn{2}{|c|}{$\begin{array}{l}\text { 1. Okuma } \\
\text { etkinlikl }\end{array}$}} & $\begin{array}{l}\text { 1. Okulda okuma saatleri ve } \\
\text { söyleşileri }\end{array}$ & $K_{3,5,7,9,10,12,13,14}$ & 8 & 14 & 57 \\
\hline & & 2. Kitap okuma yarışmaları & $\mathrm{K}_{5}$ & 1 & 14 & 7 \\
\hline & & 3. Kitap okuma projeleri & $\mathrm{K}_{2}$ & 1 & 14 & 7 \\
\hline & & 4. Kitap kahramanları günü etkinliği & $\mathrm{K}_{4}$ & 1 & 14 & 7 \\
\hline & & 5. Kitap kahramanları tiyatrosu & $\mathrm{K}_{4}$ & 1 & 14 & 7 \\
\hline & & $\begin{array}{l}\text { 6. Okul kütüphanesinde okuma } \\
\text { etkinlikleri }\end{array}$ & $\mathrm{K}_{4}$ & 1 & 14 & 7 \\
\hline
\end{tabular}


7. Sosyal medyayı kullanma

1. Okuyan öğrencilerin

2. Okumanın izlenmesi ve özendirilmesi ödüllendirilmesi

2. Okunan kitapların izlenmesi

3. Okunan kitap ile ilgili sınavlar
$\mathrm{K}_{1}$ $114 \quad 7$

$\mathrm{K}_{6,8,10,13}$

$4 \quad 14 \quad 28$

$\mathrm{K}_{3}$

$\begin{array}{lll}1 & 14 & 7\end{array}$

Okuma alışkanlığını geliştirmek için okulda yapılabilecek etkinliklerin öğretmenlerin görüşlerine göre okulda okuma etkinlikleri, okumanın izlenmesi ve özendirilmesi olmak üzere 2 ana tema ve 10 alt tema altında toplandığı belirlenmiştir.

\section{Okulda okuma etkinlikleri}

Uygulamaya katılan 11 öğretmen, "Yarışmalar, okuma saatleri, bir kitabın topluca okunup öğrencilerle değerlendirilmesi olabilir (K5), Kitap kahramanları günü düzenlemek, roman kahramanlarıyla tiyatro sergilemek (K4), Öğrenciler sosyal medyayı delice kullandıkları için okuma ile bu mecra entegre edilebilir. Ortak açılacak bir hesapla herkesin paylaşım yapması sağlanabilir (K1), Ders programına tüm okul için okuma dersi konmalı (K11)..." ifadeleriyle okuma alışkanlığını kazandırmak için okulda okuma ile ilgili etkinliklerin yapılması gerektiğini belirtmiştir.

\section{Okumanın izlenmesi ve özendirilmesi}

Uygulamaya katılan 6 öğretmen, “Edebiyat derslerinde kitap sınavı yapılmaktadır (K9), Okunan eserin paylaşımı, paylaşım yapanların ödüllendirilmesi (K10), Okuma çalışmalarında istikrarlı olup takibini yapmak (K3)..." ifadeleriyle okuma faaliyetlerinin düzenli izlenmesi ve okuyan öğrencilerin ödüllendirilmesi gerektiğini belirtmiştir.

\section{Problem}

Bu problemin çözümünde TDE öğretmenlerinin, öğrencilerinin okuma alışkanlığını geliştirmek için okul dışında yapılabilecek etkinliklere yönelik görüşlerinin incelenmesinden yararlanılmıştır. Bununla ilgili bulgular Tablo 7'de verilmiştir.

Tablo 7.

TDE Öğretmenlerine Göre Okuma Alışkanlığı lçin Okul Dışında Yapılabilecek Etkinlikler

\begin{tabular}{|c|c|c|c|c|c|c|}
\hline & Tema & $\begin{array}{l}\text { Okuma alışkanlığını okul dışında geliştirecek } \\
\text { etkinlikler }\end{array}$ & Katılımcılar & $\mathrm{n}$ & $\mathrm{N}$ & $\%$ \\
\hline & \multirow{3}{*}{ Geziler } & 1. Öğrencileri kütüphanelere götürme & $\mathrm{K}_{4,5,7,14}$ & 4 & 14 & 28 \\
\hline & & 2. Öğrencileri kitap fuarlarına götürme & $\mathrm{K}_{2,4,7,8}$ & 4 & 14 & 28 \\
\hline & & 3. Yazarı tanımak için okul gezileri yapmak & $\mathrm{K}_{4}$ & 1 & 14 & 7 \\
\hline 2. & Söyleşiler & 1. Yazarla söyleşiler ve imza günü düzenlenme & $\mathrm{K}_{5,13}$ & 1 & 14 & 14 \\
\hline \multirow[t]{3}{*}{3.} & \multirow{3}{*}{$\begin{array}{l}\text { Sosyal çevre } \\
\text { etkinlikleri }\end{array}$} & $\begin{array}{l}\text { 1. Okul dışı ortamlarda (ev, yurt ve kafelerde) } \\
\text { okuma sohbetleri yapılmalı. }\end{array}$ & $\mathrm{K}_{1,3,6,9}$ & 4 & 14 & 28 \\
\hline & & 2. Anne baba bilinçlendirilmelidir. & $\mathrm{K}_{2}$ & 1 & 14 & 7 \\
\hline & & 3. Okuma kafeleri açılabilir. & $\mathrm{K}_{11}$ & 1 & 14 & 7 \\
\hline 4. & $\begin{array}{l}\text { Okuma } \\
\text { programları }\end{array}$ & 1. Okuma projeleri yapılabilir. & $\mathrm{K}_{2}$ & 1 & 14 & 7 \\
\hline
\end{tabular}

Okuma alışkanlığını geliştirmek için okulda yapılabilecek programlar öğretmenlerin görüşlerine göre; geziler, söyleşiler, sosyal çevre etkinlikleri ve okuma programları olmak üzere 4 ana tema ve 8 alt tema altında toplandığı belirlenmiştir. 


\section{Geziler}

Öğretmenler, öğrencilere okuma alışkanlığını kazandırmak için onlarla halk kütüphanelerinin, kitapçıların sık sık ziyaret edilmesi gerektiğini belirtmişlerdir. Uygulamaya katılan öğretmenlerden 6'sı, bu tür gezilerin okuma alışkanlığının edinilmesinde yararlı olduğunu düşünmektedir. Öğretmenler, "Kütüphane gezileri bu alanda verimliliği artırır (K14), Kütüphane, kitap fuarı vb. günlük geziler (K7), Yazarları tanıtmak için gezi düzenlemek (K4)..." ifadeleriyle kütüphaneye, kitapçılara, kitap fuarlarına sık sık gitmenin faydalı olabileceğini değerlendirmiştir.

\section{Söyleşiler}

Uygulamaya katılan 3 öğretmen, "Yazarların imza ve söyleşileri izlenebilir (K5)..." ifadeleriyle öğrencilere okuma alışkanlığı kazandırmak için onların yazar söyleşilerine götürülebileceğini belirtmiştir.

\section{Sosyal çevre etkinlikleri}

Uygulamaya katılan 6 öğretmen, "Evlerde-işyerlerinde her yerde okuma faaliyeti yürütülebilir (K6), Anne-baba bilinçlendirilmelidir (K2), Sırf öğrenciler için okuma kafeleri açılabilir (K11), Öğrencilerle okul dışında özellikle doğada kitap okumak eğlendirici ve verimli olacaktır (K3), Yurtlarda veya kahvehanelerde okuma söyleşileri yapılmalıdır (K1)..."ifadeleriyle başta ailenin bilinçli olmasının, öğrencilerin yaşadıkları sosyal çevrelerinde okuma alışkanlığını geliştirici etkinliklere yer verilmesinin önemli olduğunu düşünmektedir.

\section{Okuma programları}

Uygulamaya katılan 1 öğretmen, "Projeler yapılabilir (K2)" ifadesiyle okul dışında okuma alışkanlığını geliştirmeye yönelik okuma programlarının yapılması gerektiğini belirtmiştir.

\section{Problem}

Bu problemin çözümünde öğretmenlerin, öğrencilerin okuma alışkanlığı kazanmasını engelleyen durumlara yönelik görüşlerinin incelenmesinden yararlanılmıştır. Bununla ilgili bulgular Tablo 8'de verilmiştir.

Tablo 8.

TDE Öğretmenlerine Göre Okuma Alışkanlığını Etkileyen Olumsuz Durumlar

\begin{tabular}{|c|c|c|c|c|c|c|}
\hline & Tema & Okuma alışkanlığı edinmeyi engelleyen durumlar & Katılımcılar & $\mathrm{n}$ & $\mathrm{N}$ & $\%$ \\
\hline \multirow[t]{3}{*}{1.} & Teknoloji ve & 1. Teknoloji araçları (bilgisayar, tablet, telefon) & $\mathrm{K}_{1,2,6,9,13}$ & 5 & 14 & 36 \\
\hline & sosyal & 2. Sosyal medya & $\mathrm{K}_{9}$ & 1 & 14 & 7 \\
\hline & medya & 3. Internet & $\mathrm{K}_{1}$ & 1 & 14 & 7 \\
\hline \multirow[t]{2}{*}{2} & $\begin{array}{l}\text { Okul } \\
\text { derslerinin }\end{array}$ & 1. Yoğun ders programı & $\mathrm{K}_{3,8,10,12}$ & 4 & 14 & 28 \\
\hline & yoğunluğu & 2. Zaman sorunu & $\mathrm{K}_{8}$ & 1 & 14 & 7 \\
\hline 3. & $\begin{array}{l}\text { Okuma } \\
\text { baskısı }\end{array}$ & 1. Okuma baskısı & $\mathrm{K}_{4,5,6,7}$ & 1 & 14 & 28 \\
\hline \multirow{2}{*}{\multicolumn{2}{|c|}{ 4. Sinavlar }} & 1. Çoktan seçmeliye dayanan sınav sistemi & $\mathrm{K}_{10,12}$ & 2 & 14 & 14 \\
\hline & & $\begin{array}{l}\text { 2. Velilerin dersteki akademik başarıyı } \\
\text { öncelemeleri }\end{array}$ & $\mathrm{K}_{12}$ & 1 & 14 & 7 \\
\hline & & 1. Okul kütüphanelerinin yetersizliği & $K_{3,14}$ & 2 & 14 & 14 \\
\hline & $\begin{array}{l}\text { Kitaba } \\
\text { erisim }\end{array}$ & 2. Ekonomik sıkıntı & $\mathrm{K}_{1,3}$ & 2 & 14 & 14 \\
\hline & & 3. Öğrencin doğru kitabı seçememeleri & $\mathrm{K}_{4}$ & 1 & 14 & 7 \\
\hline & Sosyal çevre & 1. Okuyan bir çevreden yoksun olma & $\mathrm{K}_{4}$ & 1 & 14 & 7 \\
\hline
\end{tabular}


Okuma alışkanlığına etki eden olumsuz etmenlerin öğretmenlerin görüşlerine göre teknoloji araçları ve sosyal medya, okul derslerinin yoğunluğu, okuma baskısı, sınavlar, kitaba erişim, sosyal çevre olmak üzere 6 ana tema ve 12 alt tema altında toplandığı belirlenmiştir.

\section{Teknoloji araçları ve sosyal medya}

Öğretmenler, öğrencilere okuma alışkanlığını kazandırmada teknolojinin olumsuz etki ettiğini belirtmişlerdir. Uygulamaya katılan öğretmenlerden $5^{\prime} \mathrm{i}$, sosyal medya kullanımının ve teknolojik aygıtlarda zaman geçirmenin kitap okumaya ayrılan zamanı azalttığı yönünde görüş bildirmişlerdir. Öğretmenler, "Hayatlarında çeldiricilerin fazla olması. İnternet, telefon gibi... (K13), Aslında yeni nesil rahat. Onları olumsuz etkileyen tek faktör interneti ve bu mecraya bağlı makineleri yanlış kullanmaları. Bu edevatın kölesi olmaları (K1), Teknoloji (bilgisayar, tablet, telefon) oyunları (K2)..."ifadeleriyle teknoloji araçlarının ve sosyal medyanın yoğun kullanımının öğrencilerde okuma alışkanlığının kazanılmasına en büyük engel olduğunu belirtmişlerdir.

\section{Okul derslerinin yoğunluğu}

Uygulamaya katılan 4 öğretmen, "Okulda ders saatlerinin çok fazla olması ve öğrencilerin kendilerine ayıracak zamanlarının çok az olmasıdır (K8), Ders yüklerinin ağır olması (K12)..." ifadeleriyle okuma alışkanlığının edinilmesinde okuldaki ders saatlerinin fazla olması öğrencilerin kendilerine zaman ayıramamalarına neden olduğunu belirtmiştir.

\section{Okuma baskısı}

Uygulamaya katılan 4 öğretmen, "Çevreden kitap okuma baskısı yapılması (K8), Onların sevmediği konularda, dili ağır olan eserleri okumaları için zorlamak sanırım (K5)..." ifadesiyle sürekli olarak baskı ve zorlama ile öğrenciye okumanın dayatılması, öğrencinin okumaya karşı olumsuz tutum geliştirmesine bunun da öğrencilerin okuma alışkanlığı kazanamamalarına neden olduğunu belirtmiştir.

\section{Kitaba erişim}

Uygulamaya katılan 4 öğretmen, "Okul kütüphaneleri zenginleştirilmelidir. Çünkü kitap fiyatları öğrenciler için yüksektir (K1), Bazı öğrencilerimizin ekonomik sıkıntıları da buraya eklenebilir (K1)..." ifadeleriyle okul kütüphanelerinin yetersiz olduğunu, ayrıca öğrencilerinin maddi yetersizlikler nedeniyle istedikleri kitaplara ulaşamadıklarını belirtmiştir.

\section{Sinavlar}

Uygulamaya katılan 2 öğretmen, "Dersler, teste dayalı sınav sistemi (K10), Akademik başarıyı daha fazla önemsemeleri, velilerin akademik başarıyı beklemeleri (K12)..." ifadeleriyle öğrencilerin ailelerinin akademik başarıyı öncelemeleri dolayısıyla, öğrencilerin de kitap okumaya zaman ayırmak yerine sınavlara çalışmayı tercih ettiklerini belirtmiştir.

\section{Sosyal çevre}

Uygulamaya katılan 1 öğretmen, "Okuyan entelektüel kişilerle karşılaşmamaları bu yaşantıyı deneyimleme şansı bulamamaları (K4)..." ifadesiyle sosyal çevrenin etkisini belirtmiştir. 


\section{Problem}

Bu problemin çözümünde TDE öğretmenlerinin, okuma alışkanlığı kazanmış öğrenciler ile okuma alışkanlığı kazanmamış öğrenciler arasında ne gibi farklııklar olduğuna yönelik görüşlerinin incelenmesinden yararlanılmıştır. Bununla ilgili bulgular Tablo 9'da verilmiştir.

Tablo 9.

TDE Öğretmenlerine Göre Okuma Alışkanlığı Kazanmış ve Kazanmamış Öğrencilerde Farklılıklar

\begin{tabular}{|c|c|c|c|c|c|}
\hline Tema & $\begin{array}{l}\text { Öğrencilerin okuma alışkanlığı kazanma } \\
\text { durumlarına göre farklılıkları }\end{array}$ & Katılımcılar & $\mathrm{n}$ & $\mathrm{N}$ & $\%$ \\
\hline \multirow{4}{*}{$\begin{array}{l}\text { 1.Anlama ve anlatma } \\
\text { becerilerini } \\
\text { geliştirme }\end{array}$} & 1. Kendini ifade etme becerileri iyidir. & $\mathrm{K}_{2,3,5,7,10,11,12}$ & 7 & 14 & 50 \\
\hline & $\begin{array}{l}\text { 2. Güzel ve etkili konuşma becerileri } \\
\text { gelişmiştir. }\end{array}$ & $\mathrm{K}_{1,2,11}$ & 3 & 14 & 21 \\
\hline & 3. Yazmaya karşı olumlu tutumları vardır. & $\mathrm{K}_{2,12}$ & 2 & 14 & 14 \\
\hline & Anlama becerileri daha iyidir. & $\mathrm{K}_{14}$ & 1 & 14 & 7 \\
\hline \multirow{5}{*}{$\begin{array}{l}\text { 2.Bilişsel becerilerini } \\
\text { geliştirme }\end{array}$} & 1. Mantık, muhakeme güçleri gelişmiştir. & $\mathrm{K}_{3,4,10}$ & 3 & 14 & 21 \\
\hline & 2. Ders başarısı daha iyidir. & $\mathrm{K}_{5,14}$ & 2 & 14 & 14 \\
\hline & 3. Yorumlama becerileri gelişmiştir. & $\mathrm{K}_{7,8}$ & 2 & 14 & 14 \\
\hline & 4. Bilişsel olarak daha iyiler. & $\mathrm{K}_{10}$ & 1 & 14 & 7 \\
\hline & 5. Düşünce dünyaları gelişmiştir. & $\mathrm{K}_{13}$ & 1 & 14 & 7 \\
\hline \multirow{3}{*}{$\begin{array}{l}\text { 3.Duyuşsal } \\
\text { becerilerini } \\
\text { geliştirme }\end{array}$} & 1. Karakterli ve olgundur. & $\mathrm{K}_{3,4,9}$ & 3 & 14 & 21 \\
\hline & Duygu dünyaları gelişmiştir. & $\mathrm{K}_{13}$ & 1 & 14 & 7 \\
\hline & 3. Özgüvenleri yüksektir. & $\mathrm{K}_{4}$ & 1 & 14 & 7 \\
\hline \multirow{3}{*}{$\begin{array}{l}\text { 4. Kültürel donanım } \\
\text { kazandırma }\end{array}$} & 1. Kültürlü davranışlar sergilerler. & $\mathrm{K}_{1}$ & 1 & 14 & 7 \\
\hline & Nitelikli sohbetlerde bulunurlar. & $\mathrm{K}_{1}$ & 1 & 14 & 7 \\
\hline & Bakış açıları gelişmiştir. & $\mathrm{K}_{10}$ & 1 & 14 & 7 \\
\hline
\end{tabular}

TDE öğretmenlerine göre okuma alışkanlığı kazanmış ve kazanmamış öğrencilerin farklılıkları 4 ana temada toplanmıştır. Bunlar; anlama ve anlatma becerilerini geliştirme, bilişsel becerilerini geliştirme, duyuşsal becerilerini geliştirme ve kültürel donanım kazandırmadır.

\section{Anlama ve anlatma becerilerini geliştirme}

Öğretmenler, okuma alışkanlığını kazanmış öğrencilerin okuma alışkanlığını kazanmamış öğrencilere göre dil becerilerinin daha gelişmiş olduğunu belirtmişlerdir. Uygulamaya katılan öğretmenlerden 9'u, okuma alışkanlığının dil becerilerinin etkin kullanımını sağladığı yönünde görüş bildirmişlerdir. Öğretmenler, "Kendini iyi ifade etme, güzel ve etkili konuşma. Yazma (hikâye, şiir) çalışmalarına meyletme (K2), Konuşma, ifade yeteneği farklılı̆ı oluşuyor (K11)..." ifadeleriyle okuma alışkanlığını kazanmış öğrencilerin anlama ve anlatma becerilerini daha etkin kullanabildiklerini belirtmişlerdir.

\section{Bilişsel becerilerini geliştirme}

Uygulamaya katılan 8 öğretmen, "Okudukları soruyu daha hızlı kavrıyorlar (K14), Okuma alışkanlığı olan öğrencilerin muhakeme güçleri gelişmektedir (K3) ..." ifadeleriyle okuma alışkanlığını kazanmış öğrencilerin anlama, kavrama ve karar verme gibi bilişsel becerilerinin diğerlerine göre daha ileri düzeyde olduğunu belirtmişlerdir.

\section{Duyuşsal becerilerini geliştirme}

Uygulamaya katılan 4 öğretmen, “Özgüvenli, ağırbaşlı çocuklar haline geliyorlar (K4), Ahlaki açıdan öğrencilere her daim olumlu etkisi olmaktadır (K9), Okuma alışkanlığı kazanmış öğrencilerin 
kişilik olarak görüşleri gelişmektedir (K3)..." ifadeleriyle okuma alışkanlığını kazanmış öğrencilerin çevresiyle daha nitelikli ilişkiler kurabildiğini ve duygusal dünyalarının da zengin olduğunu belirtmiştir.

\section{Kültürel donanım kazandırma}

Uygulamaya katılan 2 öğretmen, "Oturma-kalkmasından tutun da size davranışına, konuşmasına kadar çok farklı olabiliyorlar (K1)..." ifadesiyle okuma alışkanlığını kazanmış öğrencilerin kültürlü, deneyimli insan davranışlarını sergilediklerini belirtmiştir.

\section{Problem}

Bu problemin çözümünde TDE öğretmenlerine göre öğrencilerin okuma ilgileri ve tercihlerine yönelik görüşlerinin incelenmesinden yararlanılmıştır. Bununla ilgili bulgular Tablo $10^{\prime}$ da verilmiştir.

Tablo 10.

TDE Öğretmenlerine Göre Öğrencilerin Okuma ilgileri ve Tercihleri

\begin{tabular}{|c|c|c|c|c|c|c|}
\hline & Tema & $\begin{array}{l}\text { Öğrencilerin okuma ilgileri ve } \\
\text { tercihleri }\end{array}$ & Katılımcılar & $\mathrm{n}$ & $\mathrm{N}$ & $\%$ \\
\hline & \multirow{6}{*}{ Edebi türler } & 1. Roman & $\begin{array}{l}\mathrm{K}_{1,3,4,5,6,8,9,10} \\
11,12,13\end{array}$ & 11 & 14 & 79 \\
\hline & & 2. Şiir & $\mathrm{K}_{2,10}$ & 2 & 14 & 14 \\
\hline & & 3. Anı & $\mathrm{K}_{10}$ & 1 & 14 & 7 \\
\hline & & 4. Hikâye & $\mathrm{K}_{2}$ & 1 & 14 & 7 \\
\hline & & 5. Biyografi & $\mathrm{K}_{11}$ & 1 & 14 & 7 \\
\hline & & 6. Efsane & $\mathrm{K}_{4}$ & 1 & 14 & 7 \\
\hline & \multirow{10}{*}{ Kitap konuları } & 1. Macera & $\mathrm{K}_{3,4,5,6,8,9,10,13}$ & 8 & 14 & 57 \\
\hline & & 2. Fantastik & $\mathrm{K}_{1,9,11,12,13}$ & 6 & 14 & 43 \\
\hline & & 3. Polisiye & $\mathrm{K}_{3,5,6,9}$ & 4 & 14 & 28 \\
\hline & & 4. Aşk & $\mathrm{K}_{3,4,5,14}$ & 4 & 14 & 28 \\
\hline & & 5. Tarih & $\mathrm{K}_{2,10,14}$ & 4 & 14 & 21 \\
\hline & & 6. Korku & $\mathrm{K}_{3,5,11}$ & 3 & 14 & 21 \\
\hline & & 7. Bilim kurgu & $\mathrm{K}_{5,12,14}$ & 3 & 14 & 21 \\
\hline & & 8. Gençlik & $\mathrm{K}_{2,3}$ & 2 & 14 & 14 \\
\hline & & 9. Spor & $\mathrm{K}_{2}$ & 1 & 14 & 7 \\
\hline & & 10. Magazin & $\mathrm{K}_{1}$ & 1 & 14 & 7 \\
\hline \multirow{4}{*}{\multicolumn{2}{|c|}{$\begin{array}{l}\text { 3. Cinsiyete göre okuma } \\
\text { durumları }\end{array}$}} & 1. Kızlar daha çok okuyor. & $\mathrm{K}_{1,2,6,10,11,12,14}$ & 7 & 14 & 50 \\
\hline & & $\begin{array}{l}\text { 2. Kızlar daha disiplinli okuma } \\
\text { alışkanlığına sahip. }\end{array}$ & $K_{9,13}$ & 2 & 14 & 14 \\
\hline & & $\begin{array}{l}\text { 3. Kızlar okuma projelerinde } \\
\text { daha istekliler. }\end{array}$ & $\mathrm{K}_{1}$ & 1 & 14 & 7 \\
\hline & & 4. Cinsiyete göre farklılık yok & $\mathrm{K}_{7}$ & 1 & 14 & 7 \\
\hline & Kitabın dil ve anlatımı & $\begin{array}{l}\text { 1. Heyecan uyandıran anlatımı } \\
\text { tercih ederler. }\end{array}$ & $\mathrm{K}_{13}$ & 1 & 14 & 7 \\
\hline
\end{tabular}

TDE öğretmenlerine göre öğrencilerin hangi tür, konu, tarz kitapları okumayı sevdiğine yönelik görüşlerinin; edebi türler, kitap konuları, cinsiyete göre okuma durumları, kitabın dil ve anlatımı olmak üzere 4 ana temada toplandığı belirlenmiştir. 


\section{Edebi türler}

Uygulamaya katılan 12 öğretmen, "Roman okumayı tercih ediyorlar (K9), Güncel ve fantastik romanlar daha çok tercih ediliyor (K12), Çoğunlukla hikâye sonrasında roman, şiir (K19)..." ifadeleriyle öğrencilerin daha çok roman türünü okunduklarını bu türden sonra şiiri tercih ettiklerini belirtmiştir.

\section{Kitap konuları}

Uygulamaya katılan 14 öğretmen, “Macera konuları ilgililerini çeker ve macera kitaplarını severek okurlar (K5), Çağın getirdiği fantastik kitaplar daha fazla ilgilerini çekmektedir (K9), Daha çok gençlerin yaşamlarını konu alan kitaplar dikkatlerini çekmektedir (K3), Aşk konularını tercih ederler (K14), Sınıfa göre değişmesine rağmen magazin tarzını daha çok seviyorlar (K1)..." ifadeleriyle öğrencilerin sınıf düzeyine göre değişmekle birlikte gençlik dönem konuları ve aşk konularını okuma eğiliminde olduklarını belirtmiştir.

\section{Cinsiyete göre okuma durumları}

Uygulamaya katılan 10 öğretmen, "Kızlarda okuma alışkanlığı daha fazla (K13), Kız öğrencilerin erkeklere göre daha çok okuduklarını gözlemledim (K2)..." ifadeleriyle kızların erkeklere oranla daha çok okuma alışkanlığına sahip olduklarını belirtmiştir.

\section{Kitabın dil ve anlatımı}

Öğretmenler, öğrencilerin dil ve anlatım yönünden akıcı ve heyecan verici üslubu olan kitapları beğendiklerini ve okumayı tercih ettiklerini belirtmişlerdir. Uygulamaya katılan öğretmenlerden biri, "Heyecan uyandıran üslubu tercih ederler (K13)" ifadesiyle öğrencilerin kitap tercihinde kitapların dil ve anlatımının etkili olduğunu değerlendirmektedir. Diğer öğretmenler bu konuda herhangi bir görüş belirtmemiştir.

\section{Problem}

Bu problemin çözümünde TDE öğretmenlerine göre öğrencilerin kitap okuma nedenlerine yönelik görüşlerinin incelenmesinden yararlanılmıştır. Bununla ilgili bulgular Tablo 11'de verilmiştir.

Tablo 11.

TDE Öğretmenlerine Göre Öğrencilerin Kitap Okuma Nedenleri

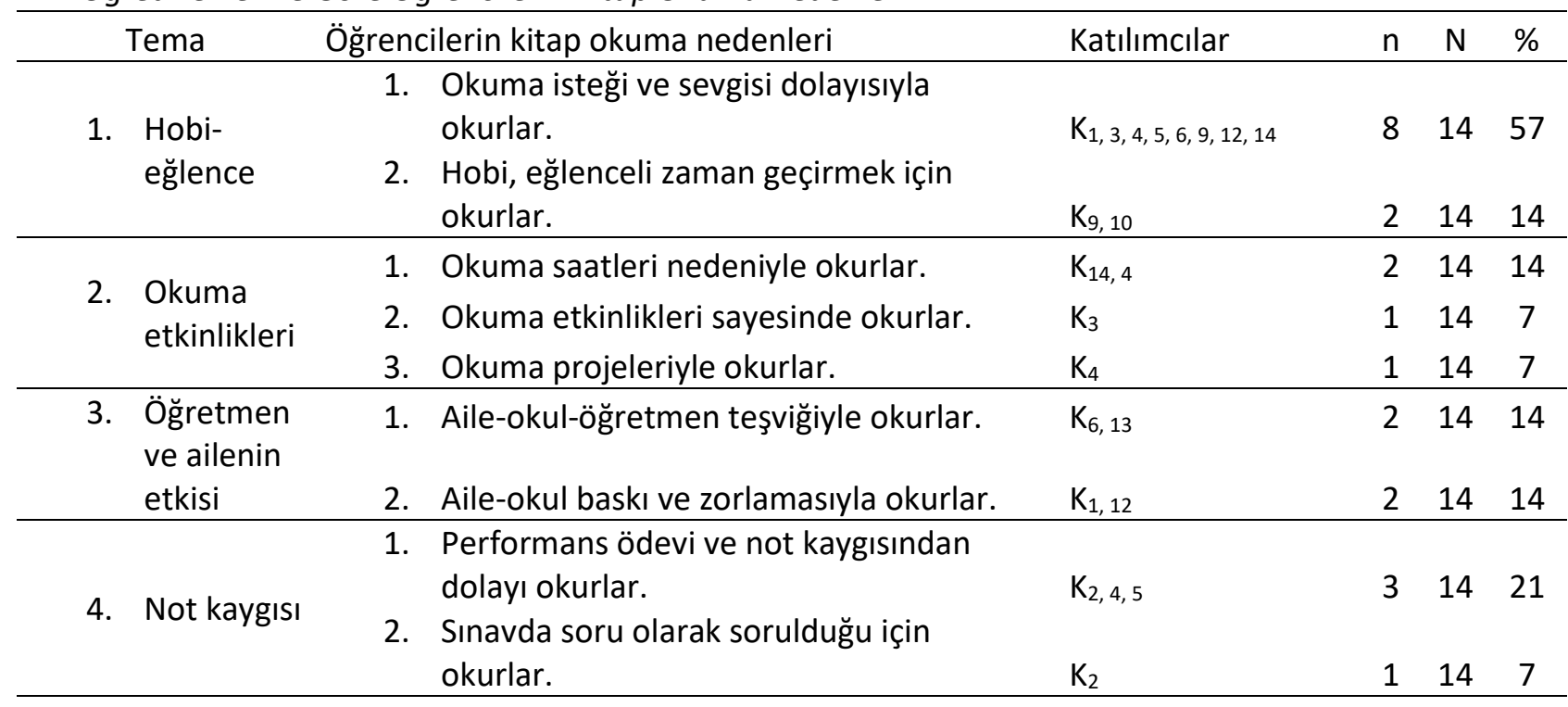

TDE öğretmenlerine göre öğrencilerin kitap okuma nedenlerine yönelik görüşlerinin; hobieğlence, okuma etkinlikleri, öğretmen ve ailenin etkisi ve not kaygısı olmak üzere 4 ana tema altında toplandığı belirlenmiştir. 


\section{Hobi-eğlence}

Uygulamaya katılan 9 öğretmen, "Çoğu severek ve kendi istediği için okuyor (K14), Çoğunlukla sürükleyici buldukları kitapları, ilgilerini çektiği için okuyorlar (K4)..." ifadeleriyle öğrencilerin okumaktan keyif aldıkları için kitap okuduklarını belirtmiştir.

\section{Öğretmen ve ailenin etkisi}

Öğretmenler, öğrencilerin baskı ve zorlamayla kitap okuduklarını belirtmişlerdir. Uygulamaya katılan 2 öğretmen, "Biraz da aile ve okulun baskısıyla okuyorlar (K12)..." ifadeleriyle öğrencilerin öğretmen ve ailelerinin istemesi ya da zorlamasıyla kitap okuduklarını belirtmişlerdir.

\section{Okuma etkinlikleri}

Uygulamaya katılan 3 öğretmen, "Okuma saatlerimizde veya performans görevleri ile projeler nedeniyle de kitap okuyorlar (K1)..." ifadeleriyle öğrencilerin düzenlenen okuma etkinlikleri sayesinde okuma yaptıklarını belirtmişlerdir.

\section{Not kaygısı}

Uygulamaya katılan 3öğretmen, "Öğretmenin not vermesi ve sınavda soru olarak sorması nedeniyle okurlar (K22)..." ifadeleriyle öğrencilerin belirlenen kitaplardan sorulacak soruları yanıtlayabilme ve yüksek not alma kaygısı nedeniyle kitap okuduklarını belirtmiştir.

\section{Problem}

Bu problemin çözümünde TDE öğretmenlerine göre öğrencilerin kitaplara nasıl eriştiğine yönelik görüşlerinin incelenmesinden yararlanılmıştır. Bununla ilgili bulgular Tablo 12' de verilmiştir.

Tablo 12.

TDE Öğretmenlerine Göre Öğrencilerin Kitaplara Erişimi

\begin{tabular}{llllllll}
\hline & \multicolumn{1}{c}{ Tema } & Öğrencilerinin kitaplara erişimi & Katılımcılar & $\mathrm{n}$ & $\mathrm{N}$ & $\%$ \\
\hline \multirow{2}{*}{ 1. } & \multirow{2}{*}{ Kütüphane } & 1. & Okul kütüphanesi & $\mathrm{K}_{1,2,3,4,5,6,7,8,9,10,13,14}$ & 12 & 14 & 86 \\
& & 2. & Halk kütüphanesi & $\mathrm{K}_{1,2,4,5,6,7,13,14}$ & 9 & 14 & 64 \\
\hline \multirow{2}{*}{ 2. } & \multirow{2}{*}{ Kitapçı ve yayınevi } & 1. & Kitapçıdan satın alma yoluyla & $\mathrm{K}_{2,4,7,12,13}$ & 5 & 14 & 36 \\
& 2. & Yayınevinden toplu kitap alımı & $\mathrm{K}_{6}$ & 1 & 14 & 7 \\
\hline \multirow{2}{*}{3.} & Kurumlar & 1. & Milli Eğitim Müdürlüğünden & $\mathrm{K}_{10,11,12}$ & 3 & 14 & 21 \\
\hline
\end{tabular}

TDE öğretmenlerine göre öğrencilerin kitaplara erişime durumları; kütüphane, kitapçı ve yayınevi, kurumlar olmak üzere 3 ana tema altında toplanmıştır.

\section{Kütüphane}

Öğretmenler, öğrencilerin kitaplara kütüphaneden eriştiğini belirtmişlerdir. Uygulamaya katılan öğretmenlerden 12'si, okul kütüphanesi ya da halk kütüphanelerinden öğrencilerin kitap temin ettiği yönünde görüş bildirmiştir. Öğretmenler, "Okulumuzun zengin bir kütüphanesi var. Orada olmayanlar için il halk kütüphanesine yönlendiriyorum (K4), Okul kütüphanesi veya il halk kütüphanesi (K2)..." ifadeleriyle öğrencilerin en çok okul kütüphanesi ve halk kütüphanelerinden kitaplara eriştiklerini belirtmişlerdir.

\section{Kitapçı ve yayınevi}

Uygulamaya katılan 6 öğretmen, "Toplu kitap alımından yararlanıyoruz (K6), Maddi durumu iyi olanlar alıyor (K2)..." ifadeleriyle öğrencilerin kitapçılardan ve yayınevlerinden satın alma yoluyla kitaplara eriştiğini belirtmiştir. 


\section{Kurumlar}

Uygulamaya katılan 3 öğretmen, "Milli Eğitim Müdürlüğü vasıtasıyla bizlere kitaplar veriliyor (K10)..." ifadesiyle öğrencilerin okullarda uygulanan okuma projeleri kapsamındaki çalışmalar sayesinde Milli Eğitim Müdürlüğünün temin ettiği kitapları okuduklarını belirtmiştir.

\section{Tartışma ve Sonuç}

TDE öğretmenlerine göre okuma alışkanlığı, ilgi ve istekle, belli aralıklarla tekrar eden, sürekli ve düzenli yapılan bir eylem ve duyuşsal açıdan öğrencinin okumaya karşı sahip olduğu olumlu bir tutumdur.

Öğretmenlere göre öğrencilerde okuma alışkanlığı ile ilgili aranan temel ölçütler; öğrencinin sürekli ve düzenli okuması ile ondaki okuma ilgi ve isteğidir. Öğrencilerin okuma eylemini sürekli yapmaları, günlük okuma yapmaları ve başladıkları bir kitabı bitirmeleri, isteyerek kitap okumaları, yanlarında kitap taşımaları ve bir kitabı bitirdikten sonra hemen yeni bir kitap arayışına girmeleri gibi özellikler onların okuma alışkanlığına sahip olduklarını gösterir. Öğretmenlere göre bu özellikleri gösteren öğrencilerin okuma kültürü edindiği söylenebilir.

TDE öğretmenlerinin geneline göre okuma alışkanlığı akademik başarıyı artııı. Aynı zamanda okuma alışkanlığı öğrencilerin dil becerilerini ve bilişsel gelişimlerini olumlu etkileyerek derslerde ve sınavlarda başarılı olmalarını sağlar. Öğretmenlerin bu görüşleri bundan önceki araştırmaların; ortaokul öğrencileri ve öğretmenleri (Karatay ve Dilekçi 2020;Sallabaş, 2008; Yaman ve Süğümlü, 2010);ortaöğretim öğrencileri (Acıyan, 2008; Gallik, 1999); lisans öğrencileri (Tatar ve Soylu, 2006) üzerine yapılan araştırma bulgularıyla örtüşsmektedir.

Öğretmenlere göre okuma alışkanlığının öğretimin her kademesinde öğrencilerin akademik başarılarını olumlu yönde etkilediği, artırdığı söylenebilir. Lise öğrencilerinin temel eğitimden itibaren edinmesi gereken bu alışkanlıklarının geliştirilmesi hem okul sınavlarında akademik başarı hem de bir üst öğretim kademesi üniversiteye geçişte onlara okumaya dayalı sınav sorularını anlamada kolaylık sağlar.

TDE öğretmenleri, öğrencilerinin okuma alışkanlığını geliştirmek için sınıfta; okuma saatleri, kitap söyleşileri, yazar ve eser tanıtımları, okuma grupları, kitapların filmlerinin izlenmesi, okuma dersleri ve yazar söyleşileri gibi etkinliklerin yapılabileceğini belirtmişlerdir. Bu etkinliklerin öğrencilerin okuma alışkanlığını geliştirmesi için öğretmenin rehber olması, okuma eylemini ödüllendirmesi ve okuma sürecini takip etmesi gerekir. Öğretmenler, bu etkinliklerin öğrencilere okuma alışkanlığı kazandırmasını öncelikle öğrencinin ilgi ve seviyesinin belirlenmesine, daha sonra sınıfta öğretmenin buna yönelik etkin çaba göstermesine bağlamıştır. Sınıf lideri olarak öğretmenin dersle ilgili öğrencilerin etkinliklere etkin katılması ve insani değerleri kazanmasında onları temsil etmesi ve bu değerleri yaşadığını göstermesi öğrenciler için en iyi örnektir. Okuma alışkanlığının da kazanıımasında öğretmenin önemli bir model olduğu bilinmektedir (Acıyan, 2008).

Lise öğrencilerinin okuma alışkanlığını geliştirmek için öğretmenlere göre okulda şu etkinlikler yapılabilir: okulda okuma saatleri ve söyleşileri, kitap okuma yarışmaları, kitap okuma projeleri, kitap kahramanları günü etkinliği, kitap kahramanları tiyatrosu, okul kütüphanesinde okuma etkinlikleri ve sosyal medyanın etkin kullanılması. Bu etkinliklerin yanında bu sürece rehberlik eden öğretmenlerin, okuma eylemini ödüllendirmesi, okuma sürecini takip etmesi ve okunan kitap ile ilgili sınavlar yapması öğrencilerin okuma ilgi ve isteğini artırır. Özellikle öğretmenlerin okumayı takip etmesi ve okuma davranışını ödüllendirmesi öğrencilerin okuma alışkanlığını kazanmalarında etkilidir (Karatay ve Dilekçi, 2020). Öğretmenlerin bu görüşleri arasında yer alan okunan kitapla ile ilgili sınavlar yapmak, başlangıçta öğrencileri kitap okumaya güdüleme açısından iyi görünebilir fakat bu sınavlar zamanla okumayı bir ihtiyaç veya eğlence olmaktan çok zorunlu hale getirir, öğrencilerin hem okula hem de okumaya karşı olumsuz bir tutum edinmesine neden olabilir. Bu durumun önüne geçmek, öğrencilerde kitaba karşı olumlu bir tutum geliştirmek ve onlara okuma alışkanlığı kazandırmak için kitap okumanın sevdirilmesi hedeflenmeli ve buna yönelik çaba gösterilmelidir.

Öğrencilerin okuma alışkanlığını etkileyen önemli etmenler okul dışındaki sosyal çevre ve eğlence alanlarıdır. Öğretmenler öğrencilere okuma alışkanlığı edindirmek için kitap gezilerinin ve yaşadıkları sosyal çevrenin etkili olduğunu belirtmişlerdir. Ayrıca okullarda yapılan okuma projeleriyle 
bu alışkanlık bütün okullarda yaygınlaştırılabilir. Bundan önceki araştırmalarda da okul dışında yapılan okuma etkinliklerinin bu alışkanlığı kazandırmada önemli bir paya sahip olduğu belirtilmiştir (Acıyan, 2008; Glasser, 1999; Karatay ve Dilekçi, 2020; Maden ve Maden, 2018). Çünkü öğrencinin davranışlarına yön veren sadece okul değil, bununla beraber aile ve sosyal çevredir.

Okuma alışkanlığının kazanılmasında belirleyici ögelerden biri ailedir. Çocukluktan itibaren aile ile birlikte yapılan okuma etkinlikleri, aile bireylerinin okuma alışkanlığına sahip olması aile içindeki her bireyi olumlu yönde etkilemektedir(Acıyan, 2008; Clark, 2010; Gaona ve González, 2011;Doiron ve Asselin, 2011; Oriogu, 2015; Ivey ve Broaddus, 2001; Karatay ve Dilekçi 2020; Karatay, Külah ve Kaya, 2020; Taşkesenlioğlu, 2013; Wicks, 1995; Yılmaz, 2004; Zickuhr vd., 2012). Okul dışında aile ortamı okuma alışkanlığının yeşermesi ve gelişmesinde en önemli etkendir.

Öğretmenlere göre okuma alışkanlığının öğrencilerde oluşmasını engelleyen en büyük etmenler; teknoloji ve sosyal medyanın aşırı kullanımıdır. Televizyon, telefon, tablet ve bilgisayara ayrılan zaman arttıkça kitap okumaya ayrılan zaman azalmaktadır. Okul derslerinin yoğun olması ve öğrencinin özellikle son sınıfta sınavlara hazırlanması okul dışı saatlerde okul derslerinin öncelenmesine ve hobi olarak dahi okuma faaliyetinin ihmal edilmesine sebep olmaktadır. Tella ve Akande'ye (2007) göre, ilköğretim öğrencilerinin okumasını olumsuz olarak en çok engelleyen etmenlerden biri televizyon izlemedir. Ortaöğretim öğrencileri daha çok telefon ve bilgisayarda, sosyal medya ve oyun uygulamalarında zaman geçirmektedir. Taşkesenlioğlu (2013), araştırmasında lise öğrencilerinin zamanlarını televizyon izlemeye ve bilgisayarla zaman geçirmeye ayırdığını ve okumalarını engelleyen en önemli sebep olarak çalışma yorgunluğunu bulgulamıştır. Bu sonuçlar gösteriyor ki teknolojik aygıtlarda geçirilen zaman arttıkça ve sınavlara hazırlanma baskısı, okumaya ayrılan süreyi azaltmaktadır. Bununla birlikte öğrencilerin bulunduğu sosyal çevrenin eğitim ve kültür açısından yeterli düzeyde olmaması bu alışkanlığın yeşermesi ve gelişmesini engeller. Ayrıca öğretmenler öğrencilerin maddi yetersizliği ya da kütüphanelerin yetersizliği nedeniyle öğrencilerin istedikleri kitaba ulaşamadıklarını belirtmişlerdir.

Öğrencilerin kitap okuma nedenlerine bakıldığında, öğrenciler kitap okumayı bir eğlence aracı olarak görmekte ve zamanı keyifle geçirmek için kitap okumaktadır. Temizyürek, Çolakoğlu ve Çoşkun (2013) ve Uslu Üstten ve Pilav'a göre de (2014) lise öğrencilerini okumaya teşvik eden nedenlerin en önemlisi okumayı sevmeleridir. Her iki araştırma bulguları birlikte değerlendirildiğinde öğrencilerde okuma eyleminin içten gelen bir istek olduğu şeklinde yorumlanabilir. Taşkesenlioğlu’ya göre (2013), lise öğrencilerinin büyük bir kısmı okuma faaliyetini ya okul derslerinde başarılı olmak için ya da boş zamanlarını değerlendirmek için gerçekleştirirler. Bu durum temel eğitim düzeyindeki öğrenciler için de aynıdır (Majid ve Tan 2007). Bu veriler birlikte değerlendirildiğinde öğrencilerin okuma nedenleri: okuldaki okuma etkinliklerine katılmak, eğlenmek, sosyal çevrenin etkisi ve okul derslerinde akademik başarı elde etme kaygısı şeklinde sıralanabilir. Bütün bunlardan en önemlisi okulda öğretmen ve evde aile, öğrencileri okumaya güdüler. Öğretmenlerin ve ailelerin bu çabalarının baskıya dönüşmesi öğrencilerin okumaya karşı olumsuz tutum geliştirmesine de neden olabilmektedir. Öğretmenler ve aileler öğrenciye kitap okuma sevgisinin aşılanması sürecinde olumlu ve ilgili bir davranış sergilemeli ve bilinçli bir çaba göstermelidir.

TDE öğretmenlerine göre okuma alışkanlığı kazanmış öğrenciler, anlama ve anlatma dil becerilerini etkin kullanmaktadır. Bu alışkanlığa sahip öğrencilerin mantık, muhakeme, yorumlama gibi üst düzey düşünme becerileri gelişmiştir. Bu öğrenciler bilişsel açıdan okuma alışkanlığı kazanmamış öğrencilere göre daha ileri düzeydedirler. Hatta duyuşsal açıdan bu öğrencilerin ahlaki davranışları ve iç dünyaları diğerlerine göre daha iyidir, sağlam karakterli ve özgüvenleri yüksektir.

Öğretmenlere göre öğrenciler kitap seçerken sırasıyla en çok; roman, şiir, anı, hikâye, biyografi, efsane türlerini tercih etmektedir. Konu olarak da; macera, fantastik, polisiye, aşk, tarih, korku, bilim kurgu, gençlik, spor ve magazin konularını içeren kitapları tercih ederler. Bundan önceki araştırma bulgularına göre de öğrencilerin, kütüphanelerde özellikle hikâye ve roman türündeki kitapları tercih ettikleri belirlenmiştir (Acıyan, 2008; Ayyıldız, Bozkurt ve Canlı, 2006; Karakoç, 2005; Taşkesenlioğlu, 2013; Vostrovsky, 1899). Bu tercihler öğrencilerin cinsiyetlerine göre de farklılaşmaktadır.

Öğretmenlere göre kız öğrenciler, okumaya karşı daha isteklidir ve daha çok kitap okumaktadır. Dolayısıyla erkeklere göre daha fazla okuma alışkanlığına sahiptir. Bu değerlendirme, farklı 
düzeylerdeki öğrenciler üzerine yapılan araştırmalarda da ortaya konmuştur (Can, Türkyılmaz, Karadeniz, 2010; Karatay ve Dilekçi, 2020; Taşkesenlioğlu, 2013; Topçu, 2005; Uslu Üstten ve Pilav, 2014).

Öğrencilerin sadece okuma alışkanlıkları değil okuma tercihleri de cinsiyetlerine göre farklılaşmaktadır. Kitap seçiminde okunan kitabın türü ve konusu kadar onu seçen öğrencinin cinsiyeti de belirleyici bir etmendir. Wicks (1995), erkek çocukların kitap seçimleri üzerine yaptığı araştırmada erkek çocukların hemen hepsinin kurgu kitaplarını okuduğunu ortaya koymuştur. Vostrovsky (1899), öğrencilerin kitap seçiminde konuyu göz önünde bulundurdukları, okuma zevkleri bakımından erkek ve kız çocukları arasında çeşitli farklııkların olduğunu; kız çocuklarının daha çok iç dünyalarını yansıtan kitaplardan, erkek çocuklarının ise macera kitaplarından hoşlandığını belirlemiştir. Uslu Üstten ve Pilav (2014), araştırmasında ise kız öğrencilerin macera, hayvan konulu ve bilim kurgu türünde kitapları tercih ettikleri; erkek öğrencilerin en fazla macera, savaş ve hırsız/dedektif konularında yazılmış kitapları okuduklarını belirlemişlerdir.

TDE öğretmenlerine göre öğrenciler en çok okul ya da halk kütüphaneleriyle kitaplara erişmektedir. İstedikleri kitap kütüphanelerde yoksa kitapçılardan satın almaktadır. Ayrıca Milli Eğitim Müdürlüğü çeşitli okuma projeleri aracılııı̆ıyla öğrencilere kitap temin etmektedir. Okuma alışkanlığının kazandırılmasında kütüphanelerin katkısı olduğu çeşitli araştırmalarda bulgulanmıştır (Clark, 2010; Gaona ve González, 2011; Majid ve Tan, 2007; Oriogu, 2015; Taşkesenlioğlu, 2013; Tella ve Akande, 2007; Wicks, 1995; Yılmaz, 2004; Zickuhr, vd., 2012 ). Alanyazındaki bu araştırma bulguları gösteriyor ki kütüphaneler, tüm öğretim kademelerindeki öğrenciler için kitaba ulaşmada temel merkez olmakla birlikte birincil bir bilgi-kültür kaynağıdır. Çocukluktan gençlik çağına dek öğrencilerin kitaba ulaşmasında kullanılan birinci yol kütüphanelerdir.

Edebiyat öğretmenleri genel olarak öğrenciler için okuma alışkanlıklarının öneminin ve onu elde etmek için okul içinde ve dışında yapılması gereken faaliyetlerin farkındadırlar. Fakat okuma alışanlığını geliştirici, ilgi çekici ve dünyada yaygın olarak kullanılan sınıf içi (rehber eşliğinde kapsamlı okuma, paylaşımlı ve etkileşimli okuma, akvaryum tekniği, Sokrates yöntemi, edebiyat halkaları) ve sınıf dışı (okuma toplulukları, web 2 araçları ve sosyal medya uygulamaları, e-kitaplar), bireysel ve grup olarak okuma teknikleri hakkında yeteri kadar bilgi sahibi oldukları söylenemez.

\section{Öneriler}

Okuma alışkanlığı lise öğrencilerinin bilişsel, duyuşsal, sosyal becerileri üzerinde yararları dikkate alındığında bu alışkanlığın kazandırılması ve geliştirilmesi için öğretmen ve ailelere önemli bir sorumluluk düşmektedir. Bu alışkanlığın kazandırılması için şunlar yapılabilir:

- Öğretmenler ve aileler, kitap okuma konusunda öğrencilere örnek olabilir.

- Öğretmen ve aileler bu alışkanlığın kazandırılması için iş birliği kurabilirler.

- Kütüphaneler her yaş grubundaki öğrencilere hitap edecek şekilde zenginleştirebilir.

- Kitap fuarı vb. etkinliklere ailece ve sınıfça geziler düzenlenebilir.

- Okunan kitaplarda geçen mekânların keşfedilmesi için ailece ve sınıf̧̧a geziler düzenlenebilir.

- Okul içinde ve dışında kitap okuma etkinlikleri, yarışmaları düzenlenebilir.

- Öğrencilerin okuma sohbetleri yapabilecekleri etkinlikler düzenlenebilir.

- Öğrencilerin gelişim düzeyleri ve ilgileri dikkate alınarak her yaş düzeyi için okuma listeleri oluşturulabilir.

- Öğrencilere beğenerek izledikleri filmlerin kitapları okutulabilir.

\section{Kaynaklar}

Acıyan, A. A. (2008). Ortaöğretim öğrencilerinin okuma alışkanlıkları ve akademik başarı düzeyleri arasındaki ilişki (Yayımlanmamış Yüksek Lisans Tezi). Yeditepe Üniversitesi, İstanbul.

Aksaçlıoğlu, A. G. ve Yılmaz, B. (2007). Öğrencilerin televizyon izlemeleri ve bilgisayar kullanmalarının okuma alışkanlıkları üzerine etkisi. Türk Kütüphaneciliği,21(1), 3-28. Retrieved from http://www.tk.org.tr/index.php/tk/article/view/8. 
Ayyıldız, M., Bozkurt, Ü. ve Canlı, S. (2006). Okuma kültürü üzerine bir araştırma. Millî Eğitim, 169, 277296.

Brown, A. L. (1980). Metacognitive development and reading. In R. J. Spiro, B. C. Bruce, \& W. F. Brewer (Eds.), The theoretical issues in reading comprehension (pp. 453-479). Hillsdale, NJ: Erlbaum.

Can, R., Türkyılmaz, M. ve Karadeniz, A. (2010). Ergenlik dönemi öğrencilerinin okuma alışkanlıkları. Ahi Evran Üniversitesi Eğitim Fakültesi Dergisi, 11 (3), 1-21.

Clark, C. (2010). Linking School Libraries and Literacy: Young People's Reading Habits and Attitudes to Their School Library and an Exploration of the Relationship between School Library Use and School Attainment. National Literacy Trust. Retrieved from https://files.eric.ed.gov/fulltext/ED513438.pdf.

Clark, C.,\&Foster, A. (2005). Children's and Young People's Reading Habits and Preferences: The Who, What, Why, Where and When. National Literacy Trust. Retrieved from https://files.eric.ed.gov/fulltext/ED541603.pdf.

Doiron, R. ve Asselin, M. (2011) Promoting a culture for reading in a diverse world. International Federation of Library Associations and Institutions, 37 (2), 109-117.

Gallik, J.D. (1999). Do they read for pleasure? Recreational reading habits of college students. Journal of Adolescent \& Adult Literacy, 42 (6), 480-489.

Gaona, J. C. G.,\&González, E. R. V. (2011). Relationship between reading habits, university library and academic performance in a sample of psychology students. Revista De La Educación Superior, 15 (157), 55-73. Retrieved from http://publicaciones.anuies.mx/pdfs/revista/Revista157_S1A3EN.pdf

Gillham, B. (2000). Case study research methods. London: Continioum House.

Glasser, W. (1999). Başarısızlığın olmadığı okul. (Çev. K. Teksöz). İstanbul: Beyaz Yayınları.

Hopper, R. (2005). What are teenagers reading? Adolescent fiction reading habits and reading choices. Literacy, 39(3), 113-120. DOi: https://doi.org/10.1111/j.1467-9345.2005.00409.x

Ivey, G. ve Broaddus, K. (2001), Justplain reading: A survey of what makes students want to read in middle school classrooms. Reading Research Quarterly, 36(4), 350-377.

Karakoç, M. (2005). Lise birinci sınıf öğrencilerinin okuma ilgi ve alışkanlıkları üzerine bir araştırma (Yayımlanmamış Yüksek Lisans Tezi). Dokuz Eylül Üniversitesi, İzmir.

Karatay, H. (2014). Okuma eğitimi kuram ve uygulama. Ankara: Pegem Akademi.

Karatay H. ve Dilekçi A. (2020). Türkçe öğretmenlerine göre öğrencilerin okuma alışkanlıkları International Journal of Languages' Education and Teaching, 8 (2), 1-24.

Karatay, H., Külah, E. ve Kaya, S. (2020). Okuma alışkanlığını geliştirme yöntem, teknik ve modelleri. Okuma Yazma Eğitimi Araştırmaları, 8 (1) , 89-107. DOI: 10.35233/oyea.707967.

Maden, S. ve Maden, A. (2018). Türkçe öğretmenlerinin okuma alışkanlığı kazandırmaya yönelik alternatif uygulamaları. Uluslararası Türk Eğitim Bilimleri Dergisi, 2018 (10), 1-17. Retrieved from https://dergipark.org.tr/tr/pub/goputeb/issue/36631/378557.

Majid, S., \& Tan, V. (2007). Understanding the reading habits of children in Singapore. 教育資料與圖 書館學， $45 \quad$ (2), $187-198 . \quad$ Retrieved from https://pdfs.semanticscholar.org/14a2/b0eadfb21524fb72861b85910f90745a3be5.pdf

Merriam, S. B. (1990) Case study research in education. San Francisco: Jossey-Bass.

Mohr, K. A. (2006). Children's choices for recreational reading: A three-part investigation of selection preferences, rationales, and processes. Journal of Literacy Research, 38 (1), 81-104. https://doi.org/10.1207/s15548430jlr3801_4

Ogunrombi, S. A.\&Adio, G. (1995). Factors affecting the reading habits of secondary school students. Library Review, $44 \quad$ (4), 50-57. Retrieved from https://www.emerald.com/insight/content/doi/10.1108/00242539510089750/full/html.

Oriogu, C. D. (2015). Catch Them Young: Developing and Improving of School Libraries and Reading Habit of Secondary School Students in Nigeria. Journal of Educationand e-Learning Research, 2 (4), 60-63. Retrieved from https://files.eric.ed.gov/fulltext/EJ1148726.pdf. 
Rimensberger, N. (2014). 'Reading is very important, but...: Takingstock of South African student teachers' reading habits', Reading \&Writing-Journal of the Reading Association of South Africa, 5 (1). http://dx.doi. org/10.4102/rw.v5i1.50.

Sallabaş, M. E. (2008). Illköğretim 8. sınıf öğrencilerinin okumaya yönelik tutumları ve okuduğunu anlama becerileri arasındaki ilişki. Inönü Üniversitesi Eğitim Fakültesi Dergisi, 9 (16), 141- 155.

Sangkaeo, S. (1999). Reading habit promotion in Asian libraries. 65th IFLA Counciland General Counciland General Conference, Bangkok, Thailand, Aug. 20-28th. Retrieved from https://files.eric.ed.gov/fulltext/ED441496.pdf.

Shen, L. (2006). Computer technology and college students' reading habits. Chia-Nan Annual Bulletin, 32, 559-572. Retrieved from http://citeseerx.ist.psu.edu/viewdoc/download?doi=10.1.1.526.1818\&rep=rep1\&type=pdf

Summers, K. (2013). Adult reading habits and preferences in relation to gender differences. Reference \& User Services Quarterly, 52 (3), 243-249. Retrieved from https://www.jstor.org/stable/pdf/refuseserq.52.3.243.pdf.

Tatar, E. ve Soylu, Y. (2006). Okuma, anlamadaki başarının matematik başarısına etkisinin belirlenmesi üzerine bir çalışma. Kastamonu Eğitim Dergisi, 14(2), 503-508.

Taşkesenlioğlu, L. (2013). Ortaöğretim Öğrencilerinin Okuma Alışkanlıkları Üzerine Bir İnceleme. Karadeniz Sosyal Bilimler Dergisi, 5 (9). Retrieved from https://dergipark.org.tr/tr/pub/ksbd/issue/16222/169898.

Tella, A.,\&Akande, S. O. (2007). Children reading habits and availability of books in Botswana primary schools: Implications for achieving quality education. The Reading Matrix 7 (2).

Temizyürek, F., Çolakoğlu, B. K., Çoşkun, S. (2013). Dokuzuncu sınıf öğrencilerinin okuma alışkanlıklarının bazı değiş̧kenler açısından incelenmesi. Türk Eğitim Bilimleri Dergisi, 11 (2), 114-150.

Topçu, Y.E. (2005). Ilköğretim 6, 7 ve 8.sınıf öğrencilerin okuma alışkanlıkları (Kayseri örneği) (Yayımlanmamış Yüksek Lisans Tezi). Gazi Üniversitesi, Ankara.

Uslu Üstten, A. ve Pilav, S. (2014). A research on high school students' reading interesrts and habits. Eğitimde Kuram ve Uygulama Journal of Theory and Practice in Education, 10 (4), 764-782.

Vostrovsky, C. (1899). A study of children's reading tastes. The Pedagogical Seminary, 6 (4), 523-535. https://doi.org/10.1080/08919402.1899.10532977.

Wicks, J. (1995). Patterns of reading among teenage boys: the reading habits and book preferences of $\begin{array}{lllll}\text { 13-15-year-old boys. New Library } & \text { 10-16. }\end{array}$ https://doi.org/10.1108/03074809510090248.

Yaman H. ve Süğümlü Ü. (2010). İlköğretim ikinci kademe öğrencilerinin ders dışı kitap okuma alışkanlıkları. Kastamonu Eğitim Dergisi, 18 (1), 291-306.

Yıldıım, A. ve Şimşek H. (2013). Sosyal bilimlerde nitel araştırma yöntemleri. Ankara: Seçkin Yayıncılık.

Yılmaz, B. (2004). Öğrencilerin okuma ve kütüphane kullanma alışkanlıklarında ebeveynlerin duyarlılığı. Bilgi Dünyası, 5 (2), 115-136.

Zickuhr, K., Rainie, L., Purcell, K., Madden, M., \&Brenner, J. (2012). Younger Americans' reading and library habits. Pew Internet \& American Life Project. Retrieved from https://files.eric.ed.gov/fulltext/ED537514.pdf.

\section{Extended Abstract}

\section{Introduction}

Reading habit can be defined as an individual's ability to perform the act of reading regularly at certain intervals, to feel the need for reading in personal life, to acquire an interest in reading and developing preferences and liking towards reading in time. In the literature, there are two main factors that affect students' acquiring of the reading habit which may be classified as positive and negative factors. Students' reading preferences and interests may change depending on their levels of development. It is known that the immediate environments of students are influential in selecting books and reading them. It is especially important that school and family environments support 
reading. The purpose of this study is to determine the features of the guidance that literature teachers provide for their students in and out of school to enable them to acquire the reading habit and improve their reading skills.

\section{Method}

In this study, the quality of the guidance teachers provided to develop the reading habit in high school students was determined. The research was designed as a case study. The participants were determined using the criterion sampling method which is one of the purposeful sampling methods and 14 volunteer teachers thus selected participated in the study. Semi-structured interview technique was used during data collection. The Reading Habit Interview Form (RHIF) was prepared for the interviews. Due to the COVID-19 pandemic, it was not possible to conduct the interviews face to face. The form was sent to the participants and they were asked to share their opinions in writing. Content analysis of the teachers' opinions was subsequently made. The answers given by the teachers were grouped per question. The participating teachers were coded using a simple letter and number system asp1, p2...where $\mathrm{p}$ stands for participant and their views were thus listed under the main and subthemes that emerged in data analysis.

\section{Results and Discussion}

According to teachers, reading habit is an action that students perform with interest and desire which is repeated continuously and regularly at certain intervals. The teachers maintain that reading habit increases students' academic success. It also positively affects their affective development and that it enables students to use their comprehension and verbal expression skills effectively in classes. Teachers stated that activities could be done in and out of school to help students acquire the habit. In the school, activities such as reading hours, book clubs, reading groups, book reading contests, theater performances based on book heroes, author and literary work introductions could be organized. Outside the school, activities such as book reading projects, trips to book fairs and bookstores, participating in author talks, and watching films based on books could be organized.

The teachers stated that parents and teachers were important in helping students acquire the reading habit. They added that the guidance they provided at school, their following the book reading processes of their students, rewarding their students for progress, offering books appropriate to their students' interests and levels and diversifying the in-class reading activities and family members' becoming models regarding reading books, having conversations about the books they finished reading and their going to book fairs and bookstores together with students enabled students to acquire the reading habit.

The teachers stated that excessive use of technology and social media prevents students from acquiring the reading habit. As the time allocated to television, smart-phone, tablet and computer use increases, the time spent for reading books decreases. Secondly, the intensity of school subjects and the preparation of final year students for the upcoming central exams limit the time spent on reading books. They also stated that when choosing books, high school students preferred books in the novel, poem, memoir, story, biography genres, and preferred books that had adventure, fantasy, crime, love, history, horror, science fiction, youth, sport and magazine themes. These preferences and reading frequencies also differed according to gender. Female students were more willing to read and read more often.

According to teachers, high school students mostly used class, school and public libraries to access books. When they could not find the books they wanted, they bought it from bookstores. This shows that schools and libraries are the primary means students use to access books from childhood to adolescence. The results show that teachers, in general, are aware of the importance of the reading habit for students and the activities that need to be done in and out of school for its acquisition. 